Cochrane Database of Systematic Reviews

\title{
Intravenous nutrients for preventing inadvertent perioperative hypothermia in adults (Review)
}

Warttig S, Alderson P, Lewis SR, Smith AF

Warttig S, Alderson P, Lewis SR, Smith AF.

Intravenous nutrients for preventing inadvertent perioperative hypothermia in adults.

Cochrane Database of Systematic Reviews 2016, Issue 11. Art. No.: CD009906.

DOI: 10.1002/14651858.CD009906.pub2.

www.cochranelibrary.com 
TABLE OF CONTENTS

HEADER 1

ABSTRACT

PLAIN LANGUAGE SUMMARY

SUMMARY OF FINDINGS

BACKGROUND

OBJECTIVES

METHODS

Figure 1.

RESULTS

Figure 2.

DISCUSSION

AUTHORS' CONCLUSIONS

ACKNOWLEDGEMENTS

REFERENCES

CHARACTERISTICS OF STUDIES

DATA AND ANALYSES

Analysis 1.1. Comparison 1 Amino acids vs no amino acids, Outcome 1 Mean core temperature, 60 minutes.

Analysis 1.2. Comparison 1 Amino acids vs no amino acids, Outcome 2 Mean core temperature, 120 minutes.

Analysis 1.3. Comparison 1 Amino acids vs no amino acids, Outcome 3 Mean core temperature at end of surgery.

Analysis 1.4. Comparison 1 Amino acids vs no amino acids, Outcome 4 Shivering.

APPENDICES

CONTRIBUTIONS OF AUTHORS

DECLARATIONS OF INTEREST

SOURCES OF SUPPORT

DIFFERENCES BETWEEN PROTOCOL AND REVIEW

INDEX TERMS 
[Intervention Review]

\title{
Intravenous nutrients for preventing inadvertent perioperative hypothermia in adults
}

\author{
Sheryl Warttig ${ }^{1}$, Phil Alderson¹, Sharon R Lewis ${ }^{2}$, Andrew F Smith 3
}

1National Institute for Health and Care Excellence, Manchester, UK. 2Patient Safety Research Department, Royal Lancaster Infirmary, Lancaster, UK. ${ }^{3}$ Department of Anaesthesia, Royal Lancaster Infirmary, Lancaster, UK

Contact address: Sheryl Warttig, National Institute for Health and Care Excellence, Level 1A, City Tower, Piccadilly Plaza, Manchester, M1 4BD, UK. sheryl.warttig@nice.org.uk.

Editorial group: Cochrane Anaesthesia Group.

Publication status and date: New, published in Issue 11, 2016.

Citation: Warttig S, Alderson P, Lewis SR, Smith AF. Intravenous nutrients for preventing inadvertent perioperative hypothermia in adults. Cochrane Database of Systematic Reviews 2016, Issue 11. Art. No.: CD009906. DOI: 10.1002/14651858.CD009906.pub2.

Copyright @ 2016 The Cochrane Collaboration. Published by John Wiley \& Sons, Ltd.

\section{A B S T R A C T}

\section{Background}

Inadvertent perioperative hypothermia (a drop in core temperature to below $36^{\circ} \mathrm{C}$ ) occurs because normal temperature regulation is disrupted during surgery, mainly because of the effects of anaesthetic drugs and exposure of the skin for prolonged periods. Many different ways of maintaining body temperature have been proposed, one of which involves administration of intravenous nutrients during the perioperative period that may reduce heat loss by increasing metabolism, thereby increasing heat production.

\section{Objectives}

To assess the effectiveness of preoperative or intraoperative intravenous nutrients in preventing perioperative hypothermia and its complications during surgery in adults.

\section{Search methods}

We searched the Cochrane Central Register of Controlled Trials (CENTRAL; November 2015) in the Cochrane Library; MEDLINE, Ovid SP (1956 to November 2015); Embase, Ovid SP (1982 to November 2015); the Institute for Scientific Information (ISI) Web of Science (1950 to November 2015); and the Cumulative Index to Nursing and Allied Health Literature (CINAHL, EBSCO host; 1980 to November 2015), as well as the reference lists of identified articles. We also searched the Current Controlled Trials website and ClincalTrials.gov.

\section{Selection criteria}

Randomized controlled trials (RCTs) of intravenous nutrients compared with control or other interventions given to maintain normothermia in adults undergoing surgery.

\section{Data collection and analysis}

Two review authors extracted data and assessed risk of bias for each included trial, and a third review author checked details if necessary. We contacted some study authors to request additional information.

\section{Main results}

We included 14 trials ( $n=565), 13(n=525)$ of which compared intravenous administration of amino acids to a control (usually saline solution or Ringer's lactate). The remaining trial $(n=40)$ compared intravenous administration of fructose versus a control. We noted much variation in these trials, which used different types of surgery, variable durations of surgery, and different types of participants. Most trials were at high or unclear risk of bias owing to inappropriate or unclear randomization methods, and to unclear participant and assessor blinding. This may have influenced results, but it is unclear how results might have been influenced. 
No trials reported any of our prespecified primary outcomes, which were risk of hypothermia and major cardiovascular events. Therefore, we decided to analyse data related to core body temperature instead as a primary outcome. It was not possible to conduct meta-analysis of data related to amino acid infusion for the 60-minute and 120-minute time points, as we observed significant statistical heterogeneity in the results. Some trials showed that higher temperatures were associated with amino acids, but not all trials reported statistically significant results, and some trials reported the opposite result, where the amino acid group had a lower core temperature than the control group. It was possible to conduct meta-analysis for six studies $(n=249)$ that provided data relating to the end of surgery. Amino acids led to a statistically significant increase in core temperature in comparison to those receiving control $\left(\mathrm{MD}=0.46^{\circ} \mathrm{C} 95 \% \mathrm{Cl} 0.33\right.$ to $0.59 ; \mathrm{I}^{2} 0.0 \%$; random-effects; moderate quality evidence).

Three trials $(n=155)$ reported shivering as an outcome. Meta-analysis did not show a clear effect, and so it is uncertain whether amino acids reduce the risk of shivering ( $\mathrm{RR} 0.36,95 \% \mathrm{Cl} 0.13$ to $1.00 ; \mathrm{I}^{2}=93 \%$; random-effects model; very low-quality evidence).

\section{Authors' conclusions}

Intravenous amino acids may keep participants up to a half-degree $C$ warmer than the control. This difference was statistically significant at the end of surgery, but not at other time points. However, the clinical importance of this finding remains unclear. It is also unclear whether amino acids have any effect on the risk of shivering and if intravenous nutrients confer any other benefits or harms, as high-quality data about these outcomes are lacking.

\section{PLAIN LANGUAGE SUMMARY}

\section{Giving intravenous nutrients to adults during surgery to prevent hypothermia}

\section{Review question}

We wanted to find out about the effects that intravenous nutrients (amino acids or sugars given into the bloodstream through a tube or a catheter in a vein) have on adults having surgery. Giving intravenous nutrients increases a person's metabolism, and this may increase the body heat produced. We wanted to know if giving intravenous nutrients during a surgical procedure could keep people warm, and if intravenous nutrients can keep them from having problems caused by being cold.

\section{Background}

People can get cold during surgery, particularly because of the drugs that are used to stop them from feeling pain and that keep them unconscious (anaesthetics). These drugs change how blood flows around the body, which can lead to heart problems and can cause wounds to heal more slowly. It may also cause blood to clot more slowly, and can make some drugs have uncertain effects. People can shiver when they wake from anaesthesia and often comment that this is a very uncomfortable experience. Keeping people warm may stop them from shivering. There are many ways of trying to keep people warm during surgery, including giving them intravenous nutrients.

\section{Study characteristics}

We looked for evidence up to November 2015. We included 14 randomized studies (involving 565 participants). Thirteen studies compared people who received normal care with additional intravenous amino acids against people who received normal care but no amino acids (the control group). One study compared people who received fructose with those in a control group. Studies involved adults undergoing planned or emergency surgery. We did not include studies in which participants were deliberately kept cold during surgery, were receiving skin grafts or were under local anaesthetic.

\section{Key results}

We can be certain that at the end of surgery, people receiving intravenous nutrients are up to a half-degree warmer than people receiving control (based on evidence from six studies involving 249 participants). However, there was more uncertainty about the effects of intravenous nutrients at other time points, with some studies suggesting that intravenous nutrients keep participants warmer and other studies reporting that participants were colder than those receiving the control. We are uncertain if keeping people up to half a degree warmer is important to those involved in caring for people who are having surgery. We are also uncertain if giving intravenous nutrients reduces the risk of people shivering (based on evidence from three studies involving 155 participants).

\section{Quality of the evidence}

Most of the evidence was moderate to low in quality. The methods used to assign participants to treatment groups was often inadequate or unclear, and we were uncertain if the people assessing outcomes were aware of which treatment group participants were in. This may have biased the results, but we are unsure what effect it may have had on results overall. 


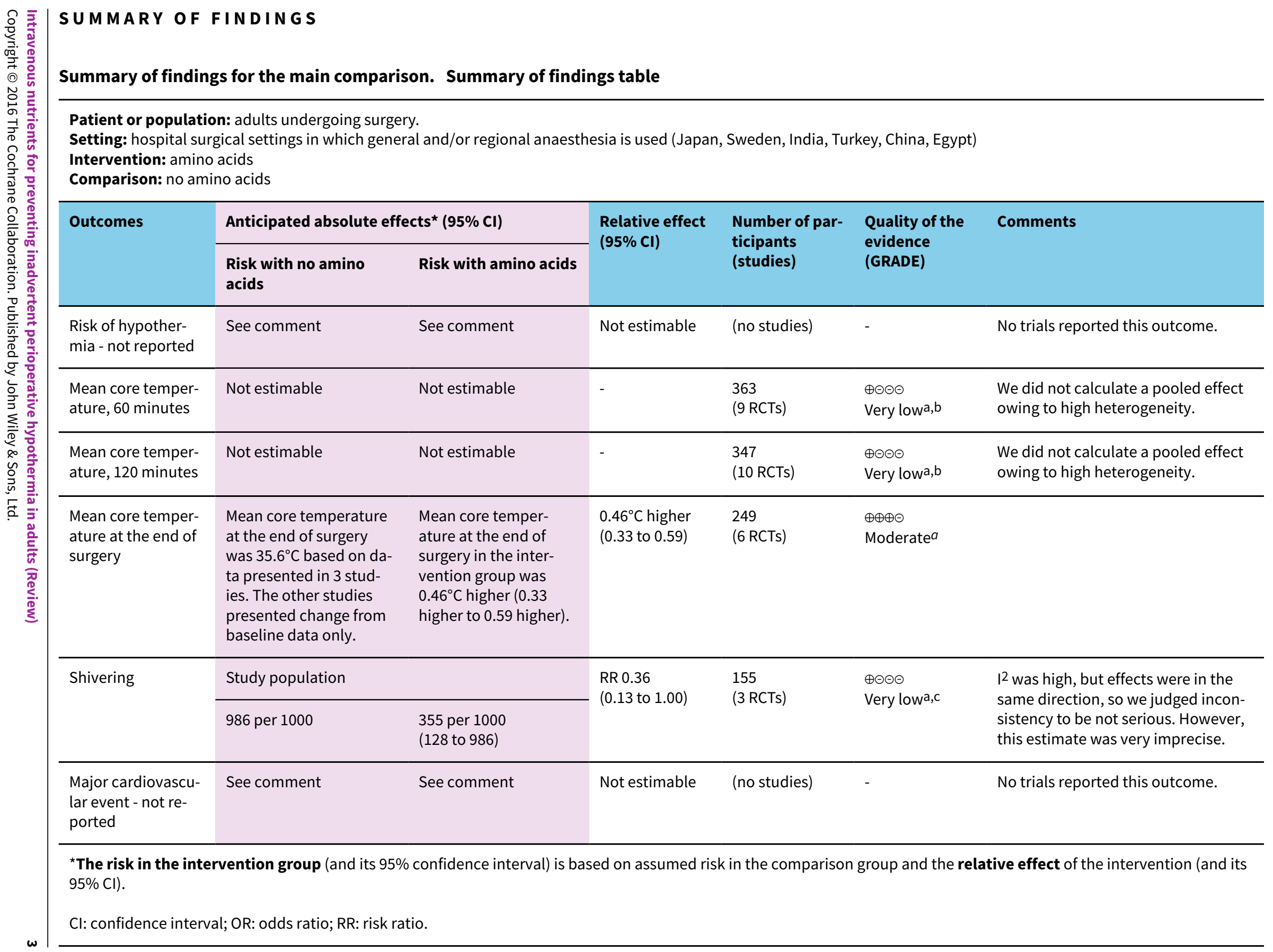




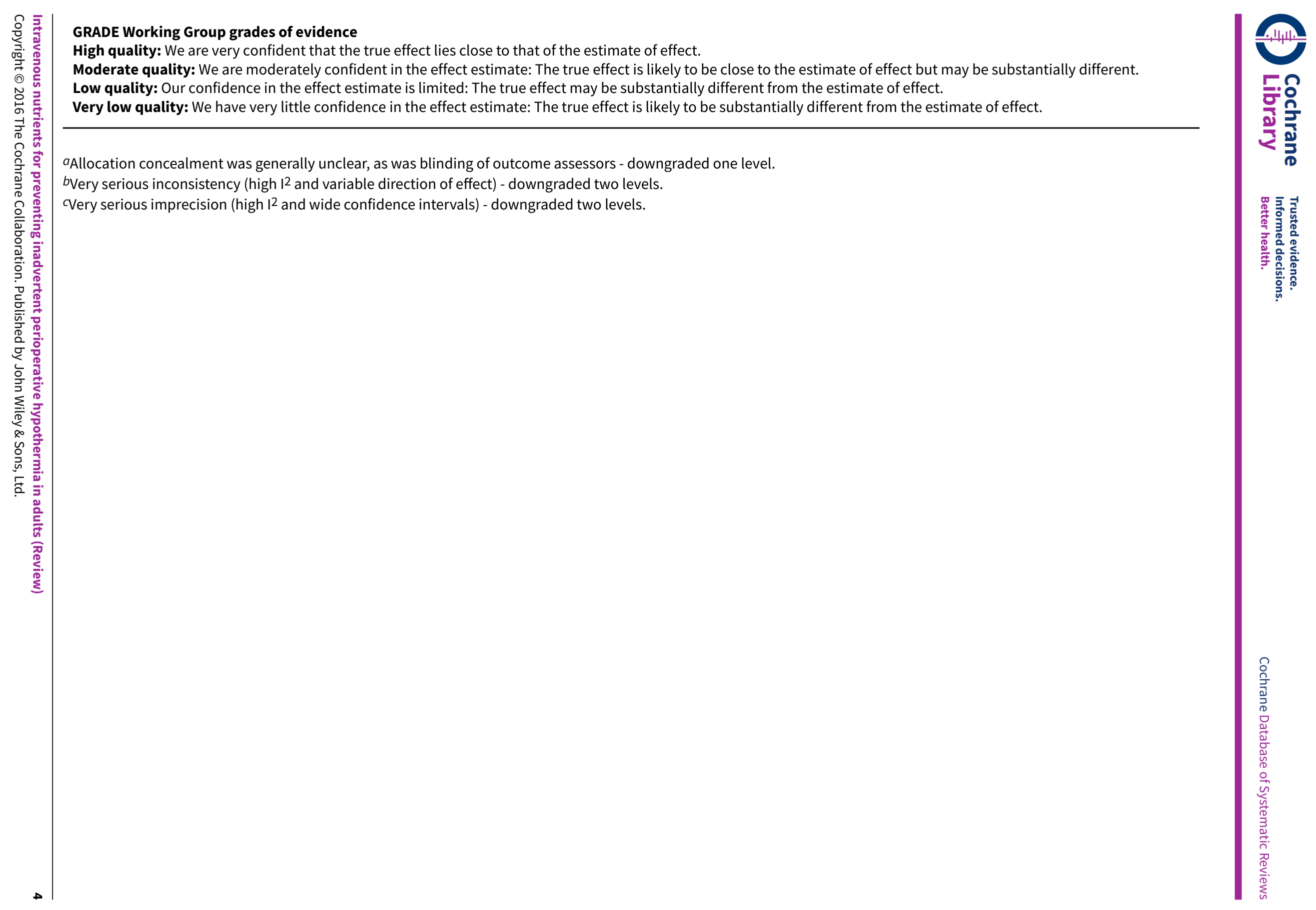




\section{B A C K G R O U N D}

\section{Description of the condition}

\section{Regulation of temperature}

Body temperature is usually maintained at between $36.5^{\circ} \mathrm{C}$ and $37.5^{\circ} \mathrm{C}$ by balancing the body's heat losses and gains. Heat is gained as a product of metabolism, including that associated with muscular activity, and is lost through convection, conduction and radiation from the skin, as well as by evaporation through sweating.

To maintain this balance, information from temperature sensors in deep tissues, and in the skin, is processed by the brain. Heat loss is increased through sweating and as a result of increased blood flow through the skin. Heat loss is reduced when blood flow through the skin is reduced, and heat production is increased mainly when muscular activity (shivering) is induced.

A useful concept in thinking about heat regulation is that the body has a central compartment comprising the major organs, where temperature is tightly regulated, and a peripheral compartment, in which temperature varies widely. Typically, temperature at the periphery may be $2^{\circ} \mathrm{C}$ to $4^{\circ} \mathrm{C}$ cooler than in the core compartment.

\section{Effects of perioperative care and anaesthesia on thermal regulation}

Exposure of the skin and internal organs during the perioperative period can increase heat loss and use of cool intravenous and irrigation fluids; inspired or insufflated (blown into body cavities) gases may directly cool people.

Sedatives and anaesthetic agents inhibit the normal response to cold, whereby surface blood vessels are constricted, effectively resulting in increased blood flow to the periphery and increased heat loss. During early stages of anaesthesia, these effects mean that the core temperature is decreased rapidly as a result of redistribution of heat from the central compartment to the peripheral compartment. Early heat loss is followed by a more gradual decline that reflects ongoing heat loss.

With epidural or spinal analgesia, peripheral blockade of vasoconstriction below the level of the nerve block may result in ongoing heat loss. Paralysis below the level of the block prevents shivering.

The risk of inadvertent perioperative hypothermia is widely variable, for example, reports from audits describe risks of 1.5\% (AlQahtani 2011) to 20\% (Harper 2008). People most susceptible to heat loss include the elderly, people with higher anaesthetic risk (American Society of Anesthesiologists (ASA) class III to IV), people with cachexia (increased metabolism associated with cancer), burn victims, people with hypothyroidism and those affected by corticoadrenal insufficiency.

\section{Complications associated with perioperative hypothermia}

Hypothermia, by altering various systems and functions, may result in increased morbidity. People often comment on subsequent shivering upon awakening from anaesthesia as one of the most uncomfortable immediate postoperative experiences. Shivering originates as a response to cold and is the result of involuntary muscular activity that occurs with the objective of increasing metabolic heat (Sessler 2001).
Cardiac complications are principal causes of morbidity during the postoperative phase. Prolonged ischaemia (as a result of reduced blood flow) is usually associated with cellular damage. For this reason, it seems that treatment of factors that can lead to such complications, such as body temperature, is likely to be important. Hypothermia stimulates the release of noradrenaline, resulting in peripheral vasoconstriction (narrowing of blood vessels) and hypertension (Sessler 1991; Sessler 2001) - factors that may favour or increase the chances of myocardial ischaemia. It appears that increased risk of cardiac complications can be reversed by maintenance of normothermia (Frank 1997).

Some studies have shown that intraoperative hypothermia accompanied by vasoconstriction constitutes an independent factor that slows wound healing and increases the risk of surgical wound infection (Kurz 1996; Melling 2001).

Even moderate hypothermia $\left(35^{\circ} \mathrm{C}\right)$ can alter physiologic coagulation mechanisms by affecting platelet function and modifying enzymatic reactions. Decreased platelet activity produces an increase in bleeding and a greater need for transfusion (Rajagopalan 2008). Moderate hypothermia can also reduce the metabolic rate, manifesting as a prolonged effect of certain drugs that are used during anaesthesia with some uncertainty about their effects. This is particularly significant in elderly people (Heier 1991; Heier 2006; Leslie 1995).

For the above reasons, inadvertent non-therapeutic hypothermia is considered an adverse effect of general and regional anaesthesia (Bush 1995; Putzu 2007; Sessler 1991). Therefore, body temperature is frequently monitored to help maintain normothermia during surgery and to detect the appearance of unintended hypothermia in a timely way.

\section{Description of the intervention}

Intravenous nutrients used to attempt to prevent inadvertent perioperative hypothermia.

\section{How the intervention might work}

Intravenous nutrients could prevent perioperative hypothermia by increasing the amount of heat an individual produces (thermogenesis), as infusion of nutrients may stimulate the body to metabolize infused nutrients and so produce heat.

\section{Why it is important to do this review}

Clinical effectiveness of the different types of devices that can be used for keeping people warm before, during, and after surgery has been assessed in a very extensive guideline commissioned by the National Insitute for Health and Care Excellence (NICE) in the UK (NICE 2008). This report concluded that evidence of clinical effectiveness and cost-effectiveness is sufficient for recommendations to be made on the use of forced air warming to prevent, and treat, perioperative hypothermia. Nevertheless, most of the data in this report pertain to intermediate outcomes such as temperature. The search strategy for this report yielded evidence only until the year 2007 , and so an updated search is needed.

This current review is one of a number of reviews in this area. Published Cochrane reviews have explored warming of gases used in minimally invasive abdominal surgery (Birch 2011), use of warmed and humidified inspired gases in ventilated 
adults (Kelly 2010), use of thermal insulation for preventing intraoperative hypothermia (Alderson 2014), use of warmed intravenous or irrigation fluids for preventing intraoperative hypothermia (Campbell 2015) and postoperative treatment of people with inadvertent hypothermia (Warttig 2014); reviews in preparation are looking into active warming (Urrútia 2011) and use of alpha-2 adrenergic agonists for prevention of shivering after general anaesthesia (Nicholson 2014).

\section{O B J E C T IVES}

To assess the effectiveness of preoperative or intraoperative intravenous nutrients in preventing perioperative hypothermia and its complications during surgery in adults.

\section{METHODS}

\section{Criteria for considering studies for this review Types of studies}

We included randomized controlled trials (RCTs) and quasirandomized controlled trials (such as allocation by alternation) of interventions used during the preoperative period (one hour before induction of anaesthesia), during the intraoperative period (total anaesthesia time) or at both times.

\section{Types of participants}

We included adults (over 18 years of age) undergoing elective and emergency surgery (including surgery for trauma) under general or regional (central neuraxial block) anaesthesia, or both.

We planned to analyse the following subgroups, if data allow: older people (> 80 years), pregnant women, ASA class I and II versus higher, duration of anaesthesia less than and longer than three hours, type (including opening thorax or abdomen versus not) and urgency (emergency or elective) of surgery.

The following groups were not covered:

1. Participants who have been treated with therapeutic hypothermia (e.g. use of cardiopulmonary bypass).

2. Participants undergoing operative procedures under local anaesthesia.

3. Participants with isolated severe head injury resulting in impaired temperature control.

4. Participants undergoing surgery for burns (e.g. for skin grafting).

\section{Types of interventions}

For this review, we focused on the following intravenous nutrients given with the intention of increasing heat production to prevent hypothermia, rather than for fluid replacement.

1. Amino acids.

2. Sugars.

3. Mixes of different nutrients.

4. Total nutrition.

We excluded comparisons of general versus regional anaesthesia.

The comparisons of interest were intravenous nutrients versus:
2. another type of intravenous nutrient.

\section{Types of outcome measures}

\section{Primary outcomes}

1. Risk of hypothermia (mild, core temperature $35.0^{\circ} \mathrm{C}$ to $35.9^{\circ} \mathrm{C}$; moderate, $34.0^{\circ} \mathrm{C}$ to $34.9^{\circ} \mathrm{C}$; severe, $<34.0^{\circ} \mathrm{C}$ ) measured at the direct tympanic membrane, bladder, oesophagus, pulmonary artery, nasopharynx or rectum. We anticipated that this would be measured and reported in a variety of ways. We sought to collect temperatures for groups at one and two hours after induction of anaesthesia and at the end of the operation, or on arrival to postanaesthesia care. We also tried to collect data on risk of hypothermia at any time after induction of anaesthesia

2. Mean core temperature. We made a post hoc decision to include this outcome after we reviewed the evidence, as none of the included studies reported risk of hypothermia (see Differences between protocol and review)

3. Major cardiovascular complications (cardiovascular death, nonfatal myocardial infarction, non-fatal stroke and non-fatal cardiac arrest)

\section{Secondary outcomes}

1. Infection and complications of surgical wound (wound healing and dehiscence) as defined by trial authors

2. Pressure ulcers, as defined by trial authors

3. Bleeding complications (blood loss, transfusions, coagulopathy)

4. Other cardiovascular complications (bradycardia, hypotension, arrhythmias)

5. Patient-reported outcomes (i.e. shivering, anxiety, comfort in postsurgical wake-up, etc.)

6. Shivering (observer reported). We made a post hoc decision to include this outcome upon reviewing the evidence, as none of the included studies described patient-reported shivering or any other patient-reported outcome (see Differences between protocol and review)

7. All-cause mortality at the end of the trial

8. Length of stay (in postanaesthesia care unit, hospital)

9. Unplanned high dependency or intensive care admission

10.Adverse effects

\section{Search methods for identification of studies}

\section{Electronic searches}

To identify eligible randomized controlled clinical trials, we searched the following electronic databases: the Cochrane Central Register of Controlled Trials (CENTRAL; 30 November 2015) in the Cochrane Library (see Appendix 1); MEDLINE, Ovid SP (1956 to 30 November 2015; see Appendix 2); Embase, Ovid SP (1982 to 30 November 2015; see Appendix 3), the Institute for Scientific Information (ISI) Web of Science (1950 to 30 November 2015; see Appendix 4); and the Cumulative Index to Nursing and Allied Health Literature (CINAHL, EBSCO host; 1980 to 30 November 2015; see Appendix 5). In searching the databases, we used both subject headings and free-text terms with no language or date restrictions. We adapted our MEDLINE search strategy for searching all other databases.

1. no intravenous nutrients; or 


\section{Searching other resources}

We also searched the following databases of ongoing trials on 30 November 2015.

1. Current Controlled Trials.

2. Clinicaltrials.gov,

\section{Data collection and analysis}

\section{Selection of studies}

We (SW and PA) independently sifted the results of literature searches to identify relevant studies, so that two people reviewed each record. We did this once for all interventions and recorded the intervention on a data extraction form (see Appendix 6). We screened 4208 articles, 4178 of which we could exclude upon reading titles and abstracts. We retrieved a full copy of the articles that could not be excluded by review of title and abstract, and we excluded another 11 articles. This left 19 studies for inclusion (see study flow diagram in Figure 1). We listed all excluded studies and reasons for exclusion in a Characteristics of excluded studies table. We resolved disagreements about inclusion or exclusion by discussion, involving another review author (AS) as necessary. 
Figure 1. Study flow diagram.

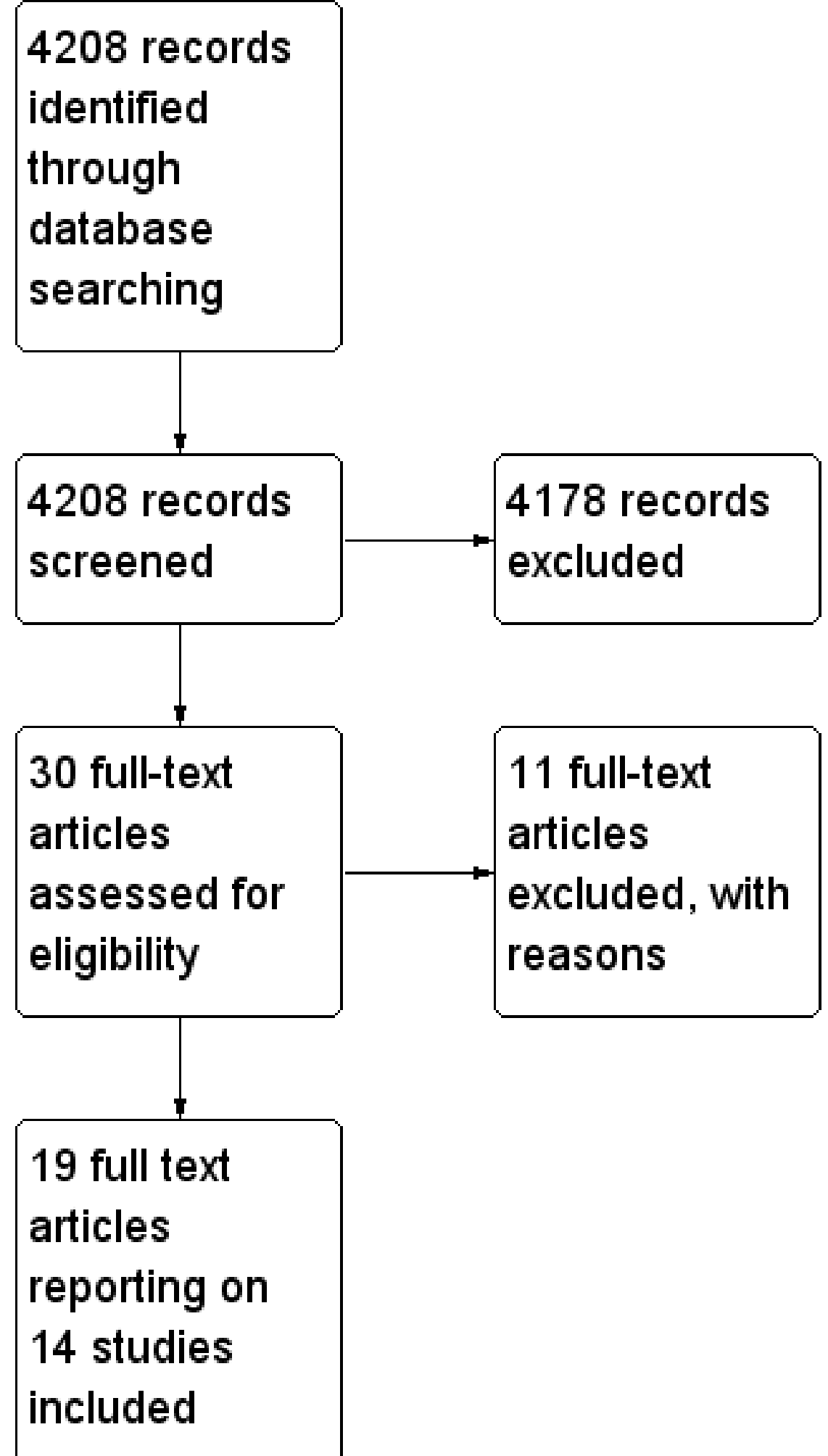

\section{Data extraction and management}

We (PA and SW) extracted relevant data independently onto a data extraction form and resolved disagreements by discussion or by consultation with a clinical expert (AS).
One review author (SW) entered the data into RevMan, and a second review author (PA) checked for transcription errors.

We extracted the following data. 
1. General information, such as title, authors, contact address, publication source, publication year and country.

2. Methodological characteristics and trial design.

3. Clinical and demographic characteristics of trial participants.

4. Description of the intervention and the control. We collected information about type of surgery, duration, surgical team experience and prophylactic antibiotic administration, when available.

5. Outcome measures as noted above.

6. Results for each trial group.

\section{Assessment of risk of bias in included studies}

We (SW and PA) independently assessed risk of bias for each trial, including those identified by the NICE guideline (NICE 2008), and for newly identified studies, using the criteria outlined in the Cochrane Handbook for Systematic Reviews of Interventions (Higgins 2011). We resolved disagreements by discussion or by consultation with a third assessor (AS)

We considered a trial as having low risk of bias if all of the following criteria were assessed as adequate. We considered a trial as having high risk of bias if one or more of the following criteria were not assessed as adequate.

1. Random sequence generation (checking for possible selection bias): We described for each included trial the methods used to generate the allocation sequence if they were provided in sufficient detail to allow an assessment of whether comparable groups were produced. We assessed methods as adequate (any truly random process, e.g. random number table, computer random number generator); inadequate (any non-random process, e.g. odd or even date of birth, hospital or clinic record number); or unclear.

2. Allocation concealment (checking for possible selection bias): We described for each included trial the method used to conceal the allocation sequence, if it was provided in sufficient detail to determine whether intervention allocation could have been foreseen in advance of or during recruitment, or changed after assignment. We assessed methods as adequate (e.g. telephone or central randomization, consecutively numbered sealed opaque envelopes); inadequate (open random allocation, unsealed or non-opaque envelopes, alternation, date of birth); or unclear.

3. Blinding of participants, personnel and outcome assessors (checking for possible performance and detection bias): We described for each included trial the methods used, if any, to blind participants, personnel and outcome assessors from knowledge of which intervention a participant received. We also provided information on whether the intended blinding was effective. If blinding was not possible, we will assess whether lack of blinding was likely to have introduced bias. Blinding was assessed separately for different outcomes or classes of outcomes. We assessed methods as adequate; inadequate; or unclear.

4. Incomplete outcome data (checking for possible attrition bias through withdrawals, drop-outs, protocol deviations): We described for each included trial and for each outcome the completeness of data including attrition and exclusions from the analysis. We stated whether attrition and exclusions were reported, the numbers included in the analysis at each stage (compared with the total number of randomized participants), reasons for attrition or exclusion when reported and whether missing data were balanced across groups or were related to outcomes. When sufficient information was reported or could be supplied by the trial authors, we re-included missing data in the analyses that we undertook. We considered intention-totreat analysis as adequate if all drop-outs or withdrawals were accounted for, and as inadequate if the number of drop-outs or withdrawals was not stated, or if reasons for drop-outs or withdrawals were not stated.

5. Selective reporting: We reported for each included trial which outcomes of interest were and were not reported. We did not plan to search for trial protocols.

6. Other bias: We described for each included trial any important concerns that we had about other possible sources of bias. We assessed whether each trial was free of other problems that could put it at risk of bias: yes; no; or unclear.

With reference to (1) to (6) above, we assessed the likely magnitude and direction of bias and whether we considered it likely to have an effect on the findings. We explored the impact of the level of bias by undertaking sensitivity analyses (see Sensitivity analysis).

\section{Measures of treatment effect}

We analysed dichotomous data by using risk ratios (RRs) with $95 \%$ confidence intervals (Cls), and continuous data by using mean differences (MDs) with $95 \% \mathrm{Cls}$.

\section{Unit of analysis issues}

We expected that most trials would be randomized by individuals, but if cluster-randomization was performed, we planned to follow advice provided in the Cochrane Handbook for Systematic Reviews of Interventions (Higgins 2011). We anticipated that other unit of analysis issues were unlikely because of the types of interventions provided and the choice of outcomes.

\section{Dealing with missing data}

When data were missing, we analysed available data on an intention-to-treat (ITT) basis.

\section{Assessment of heterogeneity}

Before obtaining pooled estimates of relative effects, we carried out a statistical heterogeneity analysis by assessing the value of the $I^{2}$ statistic, thereby estimating the percentage of total variance across studies that is due to heterogeneity rather than to chance (Higgins 2002). We considered a value greater than $30 \%$ as a sign of important heterogeneity, and we proceeded to a meta-analysis only if the direction of effect was the same for all point estimates. We explored sources of clinical heterogeneity through subgroup and sensitivity analyses.

\section{Assessment of reporting biases}

We recorded the numbers of included studies that reported each outcome. We used no statistical techniques to try to identify the presence of publication bias. We had planned to prepare a funnel plot and to analyse it by visual inspection if we found more than 10 trials for inclusion in a comparison. However, each comparison contained fewer than 10 trials, and so we did not do this. 


\section{Data synthesis}

We used random-effects model meta-analyses (DerSimonian and Laird) of risk ratios in RevMan 5.3 with 95\% confidence intervals. We analysed continuous data using mean differences (MDs) with 95\% confidence intervals.

\section{Subgroup analysis and investigation of heterogeneity}

We planned to consider subgroups based on demographic information (older people (> 80 years), pregnant women, ASA score class I and II vs higher), duration of anaesthesia and type and urgency of surgery. However, too few studies reported relevant data, and so we were not able to do this.

\section{Sensitivity analysis}

We planned to carry out sensitivity analysis according to methodologic trial quality (including only trials with low risk of bias), but lack of data prevented us from doing this.

\section{Summary of findings tables and GRADE}

We used the principles of the GRADE approach (Guyatt 2008) to assess the quality of the body of evidence associated with the specific outcomes included in our review. This approach appraises the quality of a body of evidence on the basis of the extent to which one can be confident that an estimate of effect or association reflects the item assessed. Assessment of the quality of a body of evidence considers within-study risk of bias (methodologic quality), directness of the evidence, heterogeneity of the data, precision of effect estimates and risk of publication bias. We used GRADE software to construct Summary of findings for the main comparison. We constructed a summary of findings table using the GRADE approach for the outcomes risk of hypothermia, major cardiovascular events, mean core temperature and observerreported shivering.

\section{RES U L T S}

\section{Description of studies}

\section{Results of the search}

Figure 1 summarizes results of the search conducted in November 2015. Searches yielded a total of 4208 hits. For this review, we retrieved 30 papers for consideration and included 19 of them. Five of the trials were considered subgroups of a larger trial (Sellden 1999), and so we considered these together as a single trial. Therefore, we included evidence from 14 studies. We tried to contact the authors of two studies (Demir 2002; Gupta 2009) to clarify details, but we were not able to contact them.

\section{Included studies}

We included 14 studies $(n=565)$ overall. Thirteen studies $(n=$ 525) compared amino acids versus a control (Demir 2002; Fujita 2014; Gupta 2006; Gupta 2009; Kamitani 2006; Kanazawa 2008; Kasai 2003; Mohamed 2005; Negishi 2000; Sahin 2002; Sellden 1999; Widman 2002; Zhong 2012), and one study ( $n=40)$ compared fructose versus a control (Mizobe 2006) (see Characteristics of included studies).

Four of the included studies reported a factorial design where more than one amino acid group was compared with one or more control groups. Fujita 2014 compared amino acids alone or amino acids plus glucose versus control. Kamitani 2006, compared amino acids versus a control but reported results separately for surgery lasting 180 minutes or less, and for surgery lasting longer than 180 minutes. Negishi 2000 compared different doses of amino acids versus a single control, and Sellden 1999 compared amino acids administered at different times during the perioperative period versus a single control. In these cases, we pooled the amino acids groups (and the control groups, when more than one control group existed).

Participants in the included trials received general anaesthesia, regional anaesthesia or a combination of both. One trial investigated the effects of different anaesthetic agents on the effectiveness of intravenous nutrients (Gupta 2009). For this study, we pooled anaesthetic groups in the analyses.

\section{Excluded studies}

We excluded 11 studies (Aoki 2015; Baker 1984; Carlson 1994; Chandrasekaran 2004; Donmez 1997; Fujita 2012; Hyltander 1993; Ignaki 2003; Inoue 2011; Kamitani 2005; Ohe 2014) because trials were not randomized, intravenous nutrients were used in treating hypothermia, intravenous nutrients were not used during the perioperative period, interventions were not tested during surgical therapy or a control group was not used (see Characteristics of excluded studies).

\section{Ongoing studies}

We identified no ongoing studies.

\section{Studies awaiting classification}

We found no studies awaiting classification.

\section{Risk of bias in included studies}

We provided summaries of risk of bias judgements in Figure 2. 
Figure 2. Risk of bias summary: review authors' judgements about each risk of bias item for each included study.

\begin{tabular}{|c|c|c|c|c|c|c|c|}
\hline & 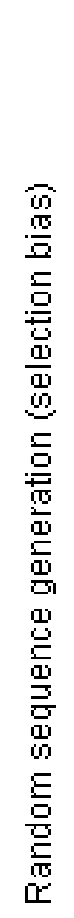 & 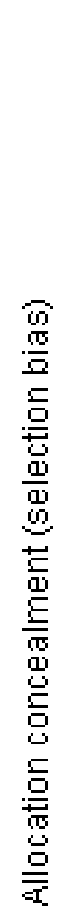 & 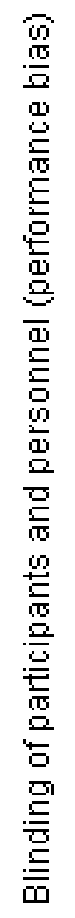 & 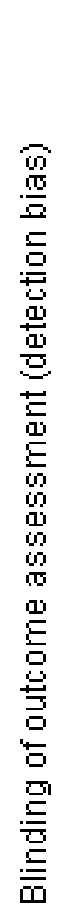 & 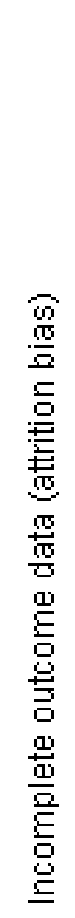 & 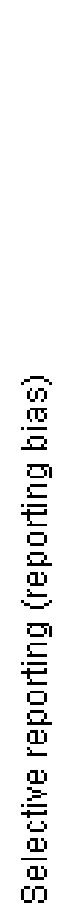 & 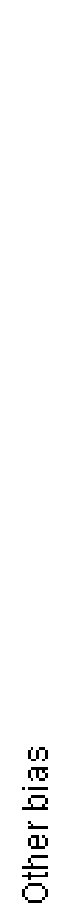 \\
\hline Demir 2002 & + & $?$ & $?$ & $?$ & $\oplus$ & $?$ & $?$ \\
\hline Fujita 2014 & $?$ & $?$ & $?$ & $?$ & + & $?$ & + \\
\hline Gupta 2006 & + & + & + & + & + & $?$ & + \\
\hline Gupta 2009 & + & $?$ & + & $?$ & + & $?$ & + \\
\hline Kamitani 2006 & $?$ & $?$ & $?$ & $?$ & + & $?$ & + \\
\hline Kanazawa 2008 & + & $?$ & $?$ & $?$ & + & $?$ & + \\
\hline Kasai 2003 & + & + & + & + & $?$ & $?$ & + \\
\hline Mizobe 2006 & + & + & $?$ & $?$ & + & $?$ & + \\
\hline Mohamed 2005 & + & $?$ & $?$ & $?$ & + & $?$ & . \\
\hline Negishi 2000 & + & $?$ & $?$ & $?$ & $?$ & $?$ & $?$ \\
\hline Sahin 2002 & + & $?$ & $?$ & $?$ & + & $?$ & + \\
\hline Sellden 1999 & + & - & $?$ & $?$ & $?$ & $?$ & + \\
\hline Widman 2002 & + & + & + & $?$ & + & $?$ & + \\
\hline Zhong 2012 & + & + & + & + & + & $?$ & ton \\
\hline
\end{tabular}




\section{Allocation}

Some trials (Demir 2002; Fujita 2014; Gupta 2009; Kamitani 2006; Kanazawa 2008; Mohamed 2005; Negishi 2000; Sahin 2002; Sellden 1999), used inappropriate randomization methods or did not report sufficient information to allow a judgement to be made, so it is unclear whether selection bias is present, and what effect this may have had on study results.

\section{Blinding}

Owing to the nature of the intervention and the fact that most participants were under general anaesthesia, participant blinding (or lack of) was considered unlikely to influence results. Most trials did not report whether outcome assessors were blinded to treatment allocation (Demir 2002; Fujita 2014; Gupta 2009; Kamitani 2006; Kanazawa 2008; Mizobe 2006; Mohamed 2005; Negishi 2000; Sellden 1999; Widman 2002). Although this could potentially bias the results, the direction of the effect that this would cause is unclear.

\section{Incomplete outcome data}

Trials included in this review were relatively short in duration, and we identified no serious issues with attrition.

\section{Selective reporting}

We did not obtain and review trial protocols, so we identified no definitive reporting biases. Included studies often did not report the outcomes chosen for this review, but it is unclear whether these data were actually collected.

\section{Other potential sources of bias}

We identified no other definitive sources of potential bias.

\section{Effects of interventions}

See: Summary of findings for the main comparison Summary of findings table

\section{Primary outcomes}

\section{Risk of hypothermia}

None of the included trials reported this outcome.

\section{Mean core temperature}

Our review protocol did not prespecify this outcome (Alderson 2012). We made a post hoc decision to include data related to mean core temperature, as none of the included studies reported risk of hypothermia (see Differences between protocol and review). We decided to summarize data by presenting mean differences at 60 minutes, at 120 minutes and at the end of surgery.

\section{Amino acids versus control, 60 minutes}

Nine trials ( $\mathrm{n}=363$; Fujita 2014; Gupta 2006; Kamitani 2006; Kanazawa 2008; Kasai 2003; Mohamed 2005; Sahin 2002; Sellden 1999; Widman 2002) compared amino acid infusion versus a control and reported mean core temperature at 60 minutes. Pooled estimates of relative effects were obtained via a random-effects model, resulting in $1^{2}=95 \%$. This was above our prespecified threshold of $30 \%$. In addition, the direction of effect was not the same for all point estimates. We noted no obvious reason for this heterogeneity and lacked power to investigate this further.
Therefore we decided to refrain from pooling the results (Analysis 1.1). In Summary of findings for the main comparison, we downgraded the evidence for this outcome by one level for risk of bias and by two levels for inconsistency.

For the four trials ( $n=146)$ with statistically significant results (Kasai 2003; Mohamed 2005; Sellden 1999; Widman 2002) and the three trials $(n=103)$ with non-statistically significant results (Fujita 2014; Gupta 2006; Kanazawa 2008), the direction of effect indicated that temperatures in the amino acids group were higher than those in the control group. However, two trials ( $n=114$; Kamitani 2006; Sahin 2002) reported results in the opposite direction by which the amino acids group had lower temperatures than the control group, although neither of these trials provided statistically significant results for this time point.

Demir $2002(n=18)$ also reported temperature outcomes at 60 minutes. The amino acids group $(n=9)$ had a mean core temperature of $35^{\circ} \mathrm{C}$, and the control group $(n=9)$ had a mean core temperature of $34.7^{\circ} \mathrm{C}$, but measures of dispersion were not reported. We chose not to estimate standard deviations for this trial.

\section{Amino acids versus control, 120 minutes}

Ten trials ( $\mathrm{n}=347$; Fujita 2014; Gupta 2006; Kamitani 2006; Kanazawa 2008; Kasai 2003; Mohamed 2005; Negishi 2000; Sellden 1999; Widman 2002; Zhong 2012) compared amino acid infusion versus a control and reported mean core temperature at 120 minutes. Pooled estimates of relative effects were obtained via a random-effects model, resulting in $1^{2}=93 \%$. This was above our prespecified threshold of $30 \%$. In addition, the direction of effect was not the same for all point estimates. We noted no obvious reason for this heterogeneity and lacked power to investigate this further. Therefore, we decided to refrain from pooling the results (Analysis 1.2). In Summary of findings for the main comparison, we downgraded the evidence for this outcome by one level for risk of bias and by two levels for inconsistency.

In general, groups receiving amino acids had higher core temperatures than control groups. This finding was statistically significant for seven trials ( $n=226$; Kanazawa 2008; Kasai 2003; Mohamed 2005; Negishi 2000; Sellden 1999; Widman 2002; Zhong 2012) but was not statistically significant for two trials ( $n=47$; Fujita 2014; Gupta 2006). One trial ( $n=74$; Kamitani 2006) reported results in the opposite direction by which the amino acids group had lower temperatures than the control group, although this result was not statistically significant.

Demir $2002(n=18)$ also reported temperature outcomes at 120 minutes. The amino acids group $(n=9)$ had a mean core temperature of $34.6^{\circ} \mathrm{C}$, and the control group $(n=9)$ had a mean core temperature of $34.6^{\circ} \mathrm{C}$, but measures of dispersion were not reported. Again, we chose not to estimate standard deviations for this trial.

\section{Amino acids versus control, end of surgery}

Six trials ( $n=249$; Fujita 2014; Gupta 2006; Kamitani 2006; Negishi 2000; Sellden 1999; Widman 2002) compared amino acid infusion versus a control and reported mean core temperature at the end of surgery; data were combined in a meta-analysis via a randomeffects model (Analysis 1.3). All point estimates showed the same direction of effect, and no significant statistical heterogeneity was 
observed $\left(\mathrm{I}^{2}=0.0 \% ; \mathrm{Chi}^{2} \mathrm{P}=0.78\right)$. Overall, at the end of surgery, amino acids were found to keep treated participants almost a halfdegree warmer than controls (MD $0.46^{\circ} \mathrm{C}, 95 \% \mathrm{Cl} 0.33$ to 0.59 ). We downgraded evidence for this outcome by one level because of risk of bias judgements.

\section{Fructose versus control}

One trial ( $n=40$; Mizobe 2006) compared effects of administration of fructose $(n=10)$ versus saline $(n=10)$ on core body temperature. Results showed a statistically significant difference between groups, favouring the fructose group, at 60 minutes (MD $0.55^{\circ} \mathrm{C}, 95 \%$ $\mathrm{Cl} 0.27$ to 0.83 ) but not at 120 minutes (MD $0.80^{\circ} \mathrm{C}, 95 \% \mathrm{Cl} 0.45$ to 0.1 .15 ). At the end of surgery, temperature differences between the two groups were statistically significant, with the fructose group more than a half-degree warmer than the group that did not receive fructose (MD $0.60^{\circ} \mathrm{C}, 95 \% \mathrm{Cl} 0.34$ to 0.63 ).

\section{Major cardiovascular complications}

None of the included trials reported this outcome.

\section{Secondary outcomes}

\section{Infection and complications of the wound (wound healing and dehiscence)}

No data were available for this outcome.

\section{Pressure ulcers, as defined by trial authors}

No data were available for this outcome.

Bleeding complications (blood loss, transfusions, coagulopathy) Amino acids versus control

Four trials ( $n=141$; Kanazawa 2008; Kasai 2003; Mohamed 2005; Widman 2002) comparing amino acid infusion versus no amino acid infusion reported mean blood loss. We did not pool these results because of the wide range of estimated mean differences and the high level of heterogeneity.

Kasai 2003 reported blood loss in the amino acids group ( $n=18$, mean $=22 \mathrm{~mL}$, standard error $(\mathrm{SE})=5)$ and in the saline group $(\mathrm{n}=$ 17 , mean $=17 \mathrm{~mL}, \mathrm{SE}=5$ ). . Results showed no statistically significant differences between groups (MD $5.00 \mathrm{~mL}, 95 \% \mathrm{Cl}-8.86$ to 18.86).

Mohamed 2005 reported blood loss in the amino acids group (n $=20$, mean $=1200 \mathrm{~mL}$, standard deviation $(\mathrm{SD})=400)$ and in the Ringer's solution group $(n=20$, mean $=1600 \mathrm{~mL}, S D=344)$. Participants in the amino acids group lost significantly less blood than those in the Ringer's solution group (MD $-400 \mathrm{~mL}, 95 \% \mathrm{Cl}$ -619.13 to -180.87$)$.

Widman 2002 reported blood loss in the amino acids group $(n=22$, mean $=516 \mathrm{~mL}, S D=272)$ and in the Ringer's solution group $(n=24$, mean $=702 \mathrm{~mL}, \mathrm{SD}=344$ ). Participants in the amino acids group lost significantly less blood than those in the Ringer's solution group (MD $-186 \mathrm{~mL}, 95 \% \mathrm{Cl}-364.49$ to -7.51 ).

Kanazawa 2008 reported blood loss in the amino acids with warmed fluids group $(n=10$, mean $=408 \mathrm{~g}, S D=454)$ and in the warmed fluids only group $(n=10$, mean $=278 \mathrm{~g}, S D=271)$. Results showed no significant differences in blood loss between the two groups (MD $130 \mathrm{~g}, 95 \% \mathrm{Cl}-197.71$ to 457.71 ).

\section{Fructose versus control}

One trial (Mizobe 2006) reported blood loss in the fructose group ( $\mathrm{n}$ $=10$, mean $=275 \mathrm{~g}, \mathrm{SD}=93)$ and in the saline group $(\mathrm{n}=10$, mean $=$ $238 \mathrm{~g}, \mathrm{SD}=79$ ). . Results showed no significant differences in blood loss between the two groups (MD $37 \mathrm{~g}, 95 \% \mathrm{Cl}-38.63$ to 112.63).

Other cardiovascular complications (bradycardia, hypotension, arrhythmias)

No data were available for this outcome.

Patient-reported outcomes (i.e. shivering, anxiety, comfort in postsurgical wake-up, etc.)

No data were available for any patient-reported outcomes.

\section{Shivering (observer rated)}

Our review protocol (Alderson 2012) did not prespecify observerrated shivering as an outcome. We made a post hoc decision to include this outcome, as it was available in the evidence and we believed that it was important.

\section{Amino acids versus control}

Three studies ( $n=155$; Mohamed 2005; Sahin 2002; Sellden 1999) reported shivering in comparisons of amino acids versus control, and results were meta-analysed via a random-effects model (Analysis 1.4). Although $1^{2}$ was 93\%, estimates were in the same direction, and so we pooled the results. We found no statistically significant differences between groups (RR $0.36,95 \% \mathrm{Cl}$ 0.13 to 1.00 ), and we downgraded the evidence to very low quality for this outcome because of risk of bias, high heterogeneity and high imprecision of the results.

\section{Fructose versus no fructose}

Investigators did not report shivering.

\section{All-cause mortality at the end of the trial}

No data were available for this outcome.

\section{Length of stay (in postanaesthesia care unit, hospital)}

Amino acids versus control

One trial ( $n=75$; Sellden 1999) reported length of hospital stay in the amino acids group $(n=45$, mean $=6.4$ days, $S D=0.3)$ compared with the control group $(n=30$, mean $=8.2$ days, $S D=0.7)$. This result was statistically significant, with participants in the amino acids group having a shorter length of stay than those in the control group (MD -1.80 days, $95 \% \mathrm{Cl}-2.07$ to -1.53 ).

\section{Fructose versus no fructose}

Investigators did not report length of hospital stay.

\section{Unplanned high dependency or intensive care admission}

No data were available for this outcome.

\section{Adverse effects}

No data were available for this outcome. 


\section{DISCUSSION}

\section{Summary of main results}

Most of the evidence included in this review was related to comparisons between amino acids and controls such as IV saline or Ringer's solution. One trial (Mizobe 2006) compared fructose versus saline. Overall the results of included evidence were mixed and could not be meta-analysed owing to significant heterogeneity. We found no clear explanations for the heterogeneity and insufficient evidence to explore it statistically. It was possible to conduct a meta-analysis for data related to the end of surgery time point. This analysis (Analysis 1.3) indicated that amino acids may keep people about a half-degree warmer than the control and may reduce the risk of shivering, but it is unclear whether this result is clinically meaningful. We found similar results in the trial comparing fructose versus control (Mizobe 2006). Amino acids appear to reduce the incidence of shivering: Although results of this study were heterogeneous, and we must be cautious about interpreting the size of the effect, the direction of effect was consistent (Analysis 1.4).

\section{Overall completeness and applicability of evidence}

Limited evidence was available overall, as most evidence was related to temperature outcomes only. Evidence related to key outcomes that we included in the review protocol was lacking, especially for adverse events, and so it is unclear whether the interventions were associated with any other benefits or harms.

The evidence included here was derived from trials involving a range of surgical situations and participant groups, and so study results are likely to be widely applicable. Subgroup analysis was not possible, and so it is unclear whether the effects of intravenous nutrients were different for different participant subgroups.

\section{Quality of the evidence}

We used the GRADE approach to assess the quality of the evidence. For results that we decided to pool, the evidence was of moderate quality, mainly because of unclear randomization and assessor blinding methods. It is unclear what effect this had on study results. For results that we decided not to pool because of high heterogeneity, we judged the quality of the evidence to be very low, for the same reasons as above, with the addition of very serious inconsistency. In addition, trials often involved very few participants, and so it is likely that they were underpowered to detect meaningful differences in outcomes, especially for rare events such as mortality.

\section{Potential biases in the review process}

Some decisions related to the analysis, particularly those regarding including outcomes such as 'core temperature' and 'shivering', and investigations of heterogeneity were undertaken after the data were reviewed. Inclusion of core temperature as a primary outcome was a post hoc decision, and the choice of time points was based on the availability of data. These decisions may have introduced bias. Outcomes in Summary of findings for the main comparison were chosen after results of the trials were noted, although this review included all primary outcomes even when no results were reported.

\section{Agreements and disagreements with other studies or reviews}

The National Insitute for Health and Care Excellence (NICE) guideline (NICE 2008) recommends forced air warming for people with a core temperature below $36^{\circ} \mathrm{C}$, those considered at high risk of hypothermia and those undergoing surgery lasting longer than 30 minutes.

We found no evidence on the comparison of intravenous nutrients versus forced air warming, and so no evidence that would corroborate or refute the NICE guideline (NICE 2008). In addition, the NICE guideline recommendations were based on modelling of the effects of temperature differences on important patient outcomes and economic analyses; we have not attempted to replicate this analysis.

\section{AUTHORS' CONCLUSIONS}

\section{Implications for practice}

Results of this review reveal moderate-quality evidence suggesting that intravenous nutrients may make people about a halfdegree warmer than controls at the end of surgery. The clinical implications of these findings are unclear. It is also unclear whether intravenous nutrients offer a temperature advantage in relation to other warming methods. High-quality evidence on important clinical outcomes is lacking.

\section{Implications for research}

High-quality randomized controlled trials are needed that should use high-quality randomization methods and blinding of clinicians and outcome assessors. Trials should examine longer-term and clinically important outcomes such as risk of clinically meaningful hypothermia and cardiovascular complications. Trials should also compare intravenous nutrients versus other warming methods.

\section{ACKNOWLEDGEMENTS}

This review builds on the work undertaken as part of the NICE clinical guideline on inadvertent perioperative hypothermia. We would like to acknowledge the work of this group.

We would like to thank Anna Lee (content editor), Jing Xie (statistical editor), Oliver Kimberger, Jonas Nygren, Tallie Casucci and Melissa Rethlefsen (peer reviewers), Janet Wale (consumer editor) for their help and editorial advice during the preparation of this systematic review

We would like to thank Anna Lee (Content Editor); Cathal Walsh (Statistical Editor); Oliver Kimberger, Janneke Horn and Rainer Lenhardt (Peer Reviewers); and Anne Lyddiatt (Consumer) for help and editorial advice provided during preparation of the protocol (Alderson 2012), for this systematic review .

We would also like to acknowledge Gillian Campbell's contribution to the original protocol (Alderson 2012). 


\section{REFERE N CES}

\section{References to studies included in this review}

Demir 2002 \{published data only\}

Demir A, Iyican D, Muslu B, Durak P, Erdemli O. Maintaining body temperature, a comparative study. Acta Anaesthesiologica Italica 2002;53:177-86. [286819219]

\section{Fujita 2014 \{published data only\}}

Fujita Y, Tokunaga C, Yamaguchi S, Horiguchi Y, Kaneko M, Iwakura T. Effect of intraoperative amino acids with or without glucose infusion on body temperature, insulin, and blood glucose levels in patients undergoing laparoscopic colectomy: a preliminary report. Acta Anaesthesioloica Taiwanica 2014;52:101-6. [PUBMED: 25085017]

\section{Gupta 2006 \{published data only\}}

Gupta N, Sehgal R, Kumar R, Sharma KR, Gupta A, Agrawal N. A prospective randomized double blind study to evaluate the effect of infusion of amino acid enriched solution on changes in surface and core temperature under general anaesthesia. Journal of Anesthesiology Clinical Pharmacology 2006;22(3):243-7. [PMC2900123]

\section{Gupta 2009 \{published data only\}}

Gupta N, Sehgal R, Kumar R, Sharma KR, Gupta A, Agrawal N. A prospective randomized double blind study to evaluate the effect of infusion of amino acid enriched solution on recovery from neuromuscular blockade. Indian Journal of Anaesthesia 2009;53(3):318-23. [PUBMED: 20640140]

\section{Kamitani 2006 \{published data only\}}

Kamitani K, Yoshida H, Takagi M, Minami M, Tokutake M, Kishi R, et al. Effect of amino acid infusion for prevention of intraoperative hypothermia during laparotomy [Japanese]. Masui 2006;55:1216-21. [PUBMED: 17051978]

\section{Kanazawa 2008 \{published data only\}}

Kanazawa M, Ando S, Suzuki T. A relationship between the effect of amino acids administered for treatment of anesthesiainduced hypothermia and the patient's muscle volume. Anesthesia and Resuscitation 2008;44:36-9. [PUBMED: 20495293]

\section{Kasai 2003 \{published data only\}}

Kasai T, Nakajima Y, Matsukawa T, Ueno H, Sunaguchi M, Mizobe T. Effect of preoperative amino acid infusion on thermoregulatory response during anaesthesia. British Journal of Anaesthesia 2003;90(1):58-61. [PUBMED: 12488380]

\section{Mizobe 2006 \{published data only\}}

Mizobe T, Nakajima Y, Ueno H, Sessler D. Fructose administration increases intraoperative core temperature by augmenting both metabolic rate and the vasoconstriction threshold. Anesthesiology 2006;104:1124-30. [PUBMED: 16732081]

\section{Mohamed 2005 \{published data only\}}

Mohamed NN, El-Raouf SA, Abd-El Hamid RM, Obayah J. The effect of amino acid infusion on body temperature, coagulopathy, blood loss, postanaesthetic shivering and metabolic requirements in abdominal surgery. Egyptian Journal of Anaesthesia 2005;21:311-6. [288732022]

\section{Negishi 2000 \{published data only\}}

Negishi C, Sessler DI, Atarashi K, Matsukawa T, Suzuki H. A large dose of amino acids prevents core hypothermia even during abdominal surgery. Anaesthesiology. 2000:A369. [1975547]

Sahin 2002 \{published data only\}

Sahin A, Aypar U. Effect of amino acid solutions on intraoperative hypothermia and post operative shivering. Acta Anaesthesiologica Scandinavica 2002;46:64-7. [PUBMED: 11903074]

\section{Sellden 1999 \{published data only\}}

Sellden E, Branstrom R, Brundin T. Augmented thermic effect of amino acids under general anaesthesia occurs predominantly in extra-splanchnic tissues. Clinical Science 1996;91:431-9. [PUBMED: 8983868]

Sellden E, Branstrom R, Brundin T. Preoperative infusion of amino acids prevents postoperative hypothermia. British Journal of Anaesthesia 1996;76:227-34. [PUBMED: 8777102]

Sellden E, Brundin T, Wahren J. Augmented thermic effect of amino acids under general anaesthesia: a mechanism useful for prevention of anaesthesia-induced hypothermia. Clinical Science 1994;86:611-8. [PUBMED: 8033514]

* Sellden E, Lindahl S. Amino acid induced thermogenesis reduces hypothermia during anaesthesia and shortens hospital stay. Anesthesia and Analgesia 1999;89:1551-6. [PUBMED: 10589647]

Sellden E, Lindahl SGE. Amino acid-induced thermogenesis to prevent hypothermia during anesthesia is not associated with increased stress response. Anesthesia and Analgesia 1998;87:637-40. [PUBMED: 9728845]

Sellden E, Lindahl SGE. Postoperative nitrogen excretion after amino acid-induced thermogenesis under anesthesia. Anesthesia and Analgesia 1998;87:641-6. [PUBMED: 9728846]

Widman 2002 \{published data only\}

Widman J, Hammarqvist F, Sellden E. Amino acid infusion induced thermogenesis and reduces blood loss during hip arthroplasty under spinal anesthesia. Regional Anesthesia 2002;95:1757-62. [PUBMED: 12456453]

\section{Zhong 2012 \{published data only\}}

Zhong J, Jin GS, Zhuang XF, Cang J, Xue ZG. Effects of intraoperative amino acid infusion on blood glucose under general anesthesia combined with epidural block. Annals of Nutrition and Metabolism 2012;61:1-6. [PUBMED: 22710812]

\section{References to studies excluded from this review}

Aoki 2015 \{published data only\}

Aoki Y, Sakai H, Uozaki N, Kou N, Takahashi K, Shiraishi Y. Changes in electrolytic concentration resulting from 
perioperative amino acid fluid administration. Masui 2015;64(2):145-9. [PUBMED: 26121805]

\section{Baker 1984 \{published data only\}}

Baker JP, Detsky AS, Stewart S, Whitwell J, Marliss EB, Jeejeebhoy KN. Randomized trial of total parenteral nutrition in critically ill patients: metabolic effects of varying glucoselipid ratios as the energy source. Gastroenterology 1984;87:53-9. [PUBMED: 6427057]

\section{Carlson 1994 \{published data only\}}

Carlson GL, Gray P, Arnold J, Little RA, Irving MH. Thermogenic, hormonal, and metabolic effects of a TPA mixture. Influence of glucose and amino acids. American Journal of Physiology Endocrinology and Metabolism. 1994; Vol. 226, issue 6:E845. [PUBMED: 8023913]

\section{Chandrasekaran 2004 \{published data only\}}

Chandrasekaran TV, Morgan RNW, Mason RA, Mangat PS, Watkins AJ, Carr ND. Nutrient induced thermogenesis during major colorectal excision- a pilot study. Colorectal Disease 2004;7:74-8. [PUBMED: 15606590]

\section{Donmez 1997 \{published data only\}}

Donmez A, Sekerci S, Arslan G. Effect of amino acid infusion on body temperature during anaesthesia. British Journal of Anaesthesia 1997;Letters:338-9. [PUBMED: 9135323]

\section{Fujita 2012 \{published data only\}}

Fujita Y, Yamaguchi S, Nakamura K, Horiguchi Y, Ikeda D, Kaneko M, et al. Effect of amino acid and glucose infusion on perioperative body temperature and postoperative infection in patients undergoing total knee arthroplasty. Japanese Journal of Anesthesiology 2012;61(1):68-73. [PUBMED: 22338863]

\section{Hyltander 1993 \{published data only\}}

Hyltander A, Arfvidsson B, Korner U, Sandstrom R, Lundholm K. Metabolic rate and nitrogen balance in patients receiving bolus intermittent total parenteral nutrition infusion. Journal of Parenteral and Enteral Nutrition 1993;17(2):158-64. [PUBMED: 8455319]

\section{Ignaki 2003 \{published data only\}}

Inagaki Y, Tubokura H, Mochida S, Funakoshi T, Ishibe Y. Thermothreshold of the start of amino acid infusion for preventing further reduction of body core temperature in elderly patients. Anesthesiology 2003;99:A905. [PUBMED: 6427057]

\section{Inoue 2011 \{published data only\}}

Inoue S, Takeaki S, Kawaguchi M, Nakajima Y, Furuya H. Amino acid infusions started after development of intraoperative core hypothermia do not affect rewarming but reduce the incidence of postoperative shivering during major abdominal surgery: a randomized trial. Journal of Anesthesia 2011;25:850-4. [PUBMED: 21927856]

\section{Kamitani 2005 \{published data only\}}

Kamitani K, Higuch A, Nohara A, Takagi M, Tokutake M, Horikawa $\mathrm{H}$, et al. Effect of amino acid solution on intraoperative core temperature- the influence of anesthetics.
Japanese Journal of Anesthesiology 2005;11:1258-62. [PUBMED: 16296364]

\section{Ohe 2014 \{published data only\}}

Ohe Y, Kunimasa K, Watanabe Y. Effects of amino acid infusion in preventing intraoperative hypothermia: comparison between sevoflurane versus propofol. Japanese Journal of Anaesthesiology 2014;63:6623-8. [PUBMED: 24979850]

\section{Additional references}

\section{Al-Qahtani 2011}

Al-Qahtani AS, Messahel FM. Benchmarking inadvertent perioperative hypothermia guidelines with the National Institute for Health and Clinical Excellence. Saudi Medical Journal 2011;32(1):27-31. [PUBMED: 21212912]

\section{Alderson 2014}

Alderson P, Campbell G, Smith A, Warttig S, Nicholson A, Lewis SR. Thermal insulation for preventing inadvertent perioperative hypothermia. Cochrane Database of Systematic Reviews 2014, Issue 6. [DOI: 10.1002/14651858.CD009908.pub2]

\section{Birch 2011}

Birch DW, Manouchehri N, Shi X, Hadi G, Karmali S. Heated $\mathrm{CO} 2$ with or without humidification for minimally invasive abdominal surgery. Cochrane Database of Systematic Reviews 2011, Issue 1. [DOI: 10.1002/14651858.CD007821.pub2]

\section{Bush 1995}

Bush HLJ, Hydo LJ, Fischer E, Fantini GA, Silane MF, Barie PS. Hypothermia during elective abdominal aortic aneurysm repair: the high price of avoidable morbidity. Journal of Vascular Surgery 1995;21(3):392-400. [PUBMED: 7877221]

\section{Campbell 2015}

Campbell G, Alderson P, Smith AS, Warttig S. Warming of intravenous and irrigation fluids for preventing inadvertent perioperative hypothermia. Cochrane Database of Systematic Reviews 2015, Issue 4. [DOI: 10.1002/14651858.CD009891.pub2]

\section{Frank 1997}

Frank SM, Fleisher LA, Breslow MJ, Higgins MS, Olson KF, Kelly S, et al. Perioperative maintenance of normothermia reduces the incidence of morbid cardiac events. A randomized clinical trial. JAMA 1997;277(14):1127-34. [PUBMED: 9087467]

\section{Guyatt 2008}

Guyatt GH, Oxman AD, Vist GE, Kunz R, Falck-Ytter Y, Alonso-Coello P, et al. GRADE Working Group. GRADE: an emerging consensus on rating quality of evidence and strength of recommendations. British Medical Journal 2008;336(7650):924-6. [PUBMED: 18436948]

\section{Harper 2008}

Harper CM, Andrzejowski JC, Alexander R. NICE and warm. British Journal of Anaesthesia 2008;101(3):293-5. [DOI: 10.1093/ bja/aen233] 


\section{Heier 1991}

Heier T, Caldwell JE, Sessler DI, Miller RD. Mild intraoperative hypothermia increases duration of action and spontaneous recovery of vecuronium blockade during nitrous oxideisoflurane anesthesia in humans. Anesthesiology 1991;74:815-9. [PUBMED: 1673591]

\section{Heier 2006}

Heier T, Caldwell JE. Impact of hypothermia on the response to neuromuscular blocking drugs. Anesthesiology 2006;104(5):1070-80. [PUBMED: 16645461]

\section{Higgins 2002}

Higgins JPT, Thompson SG. Quantifying heterogeneity in a meta-analysis. Statistics in Medicine 2002;21:1539-58. [PUBMED: 12111919]

\section{Higgins 2011}

Higgins JPT, Green S, editors. Cochrane Handbook for Systematic Reviews of Interventions, Version 5.1.0 [updated March 2011]. The Cochrane Collaboration, 2011. www.cochranehandbook.org.

\section{Kelly 2010}

Kelly M, Gillies D, Todd DA, Lockwood C. Heated humidification versus heat and moisture exchangers for ventilated adults and children. Cochrane Database of Systematic Reviews 2010, Issue 4. [DOI: 10.1002/14651858.CD004711.pub2]

\section{Kurz 1996}

Kurz A, Sessler DI, Lenhardt RA. Perioperative normothermia to reduce the incidence of surgical-wound infection and shorten hospitalization. Study of wound infections and temperature group. New England Journal of Medicine 1996;334:1209-15. [PUBMED: 8606715]

\section{Leslie 1995}

Leslie K, Sessler DI, Bjorksten AR, Moayeri A. Mild hypothermia alters propofol pharmacokinetics and increases the duration of action of atracurium. Anesthesia and Analgesia 1995;80(5):1007-14. [PUBMED: 7726398]

\section{Melling 2001}

Melling AC, Ali B, Scott EM, Leaper J. Effects of preoperative warming on the incidence of wound infection after clean surgery: a randomised controlled trial. Lancet 2001;358:876-80. [PUBMED: 11567703]

\section{NICE 2008}

The management of inadvertent perioperative hypothermia in adults: clinical guideline 65. National Institute for Health and Clinical Excellence 2008.

\section{CHARACTERISTICS OF STUDIES}

Characteristics of included studies [ordered by study ID]

\section{Nicholson 2014}

Nicholson A, Lewis SR, Alderson P, Smith AF. Alpha-2 adrenergic agonists for the prevention of shivering following general anaesthesia. Cochrane Database of Systematic Reviews 2014, Issue 5. [DOI: 10.1002/14651858.CD011107]

\section{Putzu 2007}

Putzu M, Casati A, Berti M, Pagliarini G, Fanelli G. Clinical complications, monitoring and management of perioperative mild hypothermia: anesthesiological features. Acta Biomedica 2007;78(3):163-9. [PUBMED: 18330074]

\section{Rajagopalan 2008}

Rajagopalan S, Mascha E, Na J, Sessler DI. The effects of mild perioperative hypothermia on blood loss and transfusion requirement. Anesthesiology 2008;108(1):71-7. [PUBMED: 18156884]

\section{Sessler 1991}

Sessler DI, Rubinstein EH, Moayeri A. Physiologic responses to mild perianesthetic hypothermia in humans. Anesthesiology 1991;75:594-610. [PUBMED: 1928769]

\section{Sessler 2001}

Sessler D. Complications and treatment of mild hypothermia. Anesthesiology 2001;95:531-43. [PUBMED: 9148354]

\section{Urrútia 2011}

Urrútia G, Roqué i Figuls M, Campos JM, Paniagua P, Cibrian Sánchez S, Maestre L, et al. Active warming systems for preventing inadvertent perioperative hypothermia in adults. Cochrane Database of Systematic Reviews 2011, Issue 3. [DOI: 10.1002/14651858.CD009016]

\section{Warttig 2014}

Warttig S, Alderson P, Campbell G, Smith AF. Interventions for treating inadvertent postoperative hypothermia. Cochrane Database of Systematic Reviews 2014, Issue 11. [DOI: 10.1002/14651858.CD009892.pub2]

\section{References to other published versions of this review Alderson 2012}

Alderson P, Campbell G, Smith A, Warttig S. Pharmacological agents for preventing inadvertent perioperative hypothermia. Cochrane Database of Systematic Reviews 2012, Issue 6. [DOI: 10.1002/14651858.CD009906]

* Indicates the major publication for the study

Demir 2002

Methods Single-centre trial conducted in Turkey


Demir 2002 (Continued)

Participants
27 patients scheduled for major abdominal surgery. Patients with metastatic malignant disease or secondary disease were not included.

Premedication: $0.07 \mathrm{mg} / \mathrm{kg}$ midazolam, $0.5 \mathrm{mg}$ morphine i.m.

Induction of anaesthesia: $5 \mathrm{mg} / \mathrm{kg}$ pentothal, $0.1 \mathrm{mg} / \mathrm{kg}$ fentanyl, $0.1 \mathrm{mg} / \mathrm{kg}$ rocuronium

Maintenance of anaesthesia: $1 \%-2 \%$ isoflurane, $40 \%$ oxygen, $60 \%$ nitrous oxide

Mean age: not stated

Male/female: not stated

Interventions

No extra warming $(n=9)$ : routine anaesthesia with conventional techniques. Intravenous fluids at room temperature. No extra warming or amino acids used

Amino acids ( $n=9)$ : Freamin 17 amino acids solution via jugular vein infused at $143 \mathrm{~mL} / \mathrm{h}$ throughout anaesthesia

Warmed fluids ( $n=9)$ : intravenous fluids warmed to $37^{\circ} \mathrm{C}$ with Animec AM-4 heater. This was stopped at the end of anaesthesia.

\begin{tabular}{ll}
\hline Outcomes & Rectal temperature and nasopharyngeal temperature $\left({ }^{\circ} \mathrm{C}\right)$ every 30 minutes, pain scores, shivering \\
\hline Notes & This study was supported by hospital funds. Conflicts of interest are not reported.
\end{tabular}

\section{Risk of bias}

\begin{tabular}{|c|c|c|}
\hline Bias & Authors' judgement & Support for judgement \\
\hline $\begin{array}{l}\text { Random sequence genera- } \\
\text { tion (selection bias) }\end{array}$ & Low risk & 'Patients were randomly assigned to constitute 3 groups' \\
\hline $\begin{array}{l}\text { Allocation concealment } \\
\text { (selection bias) }\end{array}$ & Unclear risk & Not stated \\
\hline $\begin{array}{l}\text { Blinding of participants } \\
\text { and personnel (perfor- } \\
\text { mance bias) } \\
\text { All outcomes }\end{array}$ & Unclear risk & Not stated \\
\hline $\begin{array}{l}\text { Blinding of outcome as- } \\
\text { sessment (detection bias) } \\
\text { All outcomes }\end{array}$ & Unclear risk & Not stated \\
\hline $\begin{array}{l}\text { Incomplete outcome data } \\
\text { (attrition bias) } \\
\text { All outcomes }\end{array}$ & Low risk & No loss to follow-up \\
\hline $\begin{array}{l}\text { Selective reporting (re- } \\
\text { porting bias) }\end{array}$ & Unclear risk & Not assessed \\
\hline Other bias & Unclear risk & $\begin{array}{l}\text { Study authors did not provide analysis of baseline characteristics; therefore, it } \\
\text { is unclear if groups were equally matched. }\end{array}$ \\
\hline
\end{tabular}


Fujita 2014

\begin{tabular}{|c|c|}
\hline Methods & Single-centre trial conducted in Japan \\
\hline \multirow[t]{7}{*}{ Participants } & $\begin{array}{l}21 \text { patients undergoing elective colectomy under general anaesthesia with ASA status I or II. Patients } \\
\text { were excluded if they had history of diabetes and/or BMI }>30 \text {; preoperative receipt of sedatives, anal- } \\
\text { gesics or antidepressants; preoperative C-reactive protein level }>1.0 \mathrm{mg} / \mathrm{dL} \text {; blood glucose level }>126 \\
\mathrm{mg} / \mathrm{dL} \text { and/or body temperature }>37.5^{\circ} \mathrm{C} \text { after anaesthetic induction; or surgical time }>500 \text { minutes }\end{array}$ \\
\hline & Premedication: none \\
\hline & Induction of anaesthesia: $1.2-2 \mathrm{mg} / \mathrm{kg}$ propofol, $2-4 \mathrm{\mu g} / \mathrm{kg}$ fentanyl and $0.9 \mathrm{mg} / \mathrm{kg}$ rocuronium \\
\hline & $\begin{array}{l}\text { Maintenance of anaesthesia: } 1 \%-1.5 \% \text { sevoflurane and continuous infusion of remifentanil (0.05-0.25 } \\
\mu \mathrm{g} / \mathrm{kg} / \mathrm{min})\end{array}$ \\
\hline & $\begin{array}{l}\text { For intraoperative pain control, a } 5-7 \mathrm{~mL} \text { bolus of } 0.375 \% \text { ropivacaine was followed by a continuous in- } \\
\text { fusion of } 2 \mathrm{~mL} / \mathrm{h} \text { beginning } 10 \text { minutes before skin incision, and lasting until the end of surgery }\end{array}$ \\
\hline & $\begin{array}{l}\text { Mean age: } \text { control: } \text { mean }=68 \text { years, } S D=9 ; \text { amino acids only: } \text { mean }=68 \text { years, } S D=10 ; \text { amino acids + } \\
\text { glucose: } \text { mean }=67 \text { years, } S D=7\end{array}$ \\
\hline & $\begin{array}{l}\text { Male/female: control: } 5 \text { male, } 2 \text { female; amino acids only: } 5 \text { male, } 1 \text { female; amino acids + glucose: } 3 \\
\text { male, } 5 \text { female }\end{array}$ \\
\hline
\end{tabular}

Interventions Control $(n=7)$ : Ringer's acetate solution at $5 \mathrm{~mL} / \mathrm{kg} / \mathrm{h}$

Amino acids only $(\mathrm{n}=6)$ : Ringer's acetate solution at $5 \mathrm{~mL} / \mathrm{kg} / \mathrm{h}$ plus $200 \mathrm{~mL} / \mathrm{h}$ amino acids at $200 \mathrm{~mL} / \mathrm{h}$ for 1.5 hours after surgery initiation

Amino acids + glucose $(n=8)$ : Ringer's acetate solution at $5 \mathrm{~mL} / \mathrm{kg} / \mathrm{h}$ plus amino acids at $200 \mathrm{~mL} / \mathrm{h}$ for 1.5 hours after surgery initiation plus glucose infusion at $2 \mathrm{mg} / \mathrm{kg} / \mathrm{min}$ administered at anaesthesia induction and for the duration of surgery

All participants received forced air warming during surgery, which was set at $38^{\circ} \mathrm{C}$ and was positioned over the precordium and upper limbs.

All participants received up to $200 \mathrm{mg}$ sugammadex to antagonize neuromuscular blockade and facilitate emergence from general anaesthesia.

The operating room was maintained at $26^{\circ} \mathrm{C}$ until anaesthesia induction; the room was then cooled to about $23^{\circ} \mathrm{C}$ during surgery, then was warmed to $26^{\circ} \mathrm{C}$ near the end of surgery.

\begin{tabular}{ll}
\hline Outcomes & Tympanic membrane temperature \\
\hline Notes & $\begin{array}{l}\text { This research was funded by departmental sources. Conflict of interest was described, and none were } \\
\text { declared. }\end{array}$
\end{tabular}

\section{Risk of bias}

\begin{tabular}{lll}
\hline Bias & Authors' judgement & Support for judgement \\
\hline $\begin{array}{l}\text { Random sequence genera- } \\
\text { tion (selection bias) }\end{array}$ & Unclear risk & Not stated \\
\hline $\begin{array}{l}\text { Allocation concealment } \\
\text { (selection bias) }\end{array}$ & Unclear risk & Not stated \\
\hline $\begin{array}{l}\text { Blinding of participants } \\
\text { and personnel (perfor- } \\
\text { mance bias) } \\
\text { All outcomes }\end{array}$ & Unclear risk & Not stated \\
\hline
\end{tabular}


Fujita 2014 (Continued)

Blinding of outcome as-
sessment (detection bias) $\quad$ Unclear risk $\quad$ Not stated

All outcomes

\begin{tabular}{lll}
\hline $\begin{array}{l}\text { Incomplete outcome data } \\
\text { (attrition bias) } \\
\text { All outcomes }\end{array}$ & Low risk & No loss to follow-up \\
\hline $\begin{array}{l}\text { Selective reporting (re- } \\
\text { porting bias) }\end{array}$ & Unclear risk & Not assessed \\
\hline Other bias & Low risk & No other concerns \\
\hline
\end{tabular}

\section{Gupta 2006}

\begin{tabular}{|c|c|}
\hline Methods & Single-centre trial conducted in India \\
\hline \multirow[t]{6}{*}{ Participants } & $\begin{array}{l}63 \text { adults ASA grade I/II (aged } 20-60 \text { years) admitted for elective surgery under general anaesthesia. Pa- } \\
\text { tients undergoing emergency surgery with known hepatic thyroid or renal disease, known allergy to } \\
\text { study drug and } \mathrm{BMI}>30 \text { or }<20 \mathrm{~kg} / \mathrm{m}^{2} \text { were excluded from the study. }\end{array}$ \\
\hline & Premedication: $2 \mathrm{mcg} / \mathrm{kg}$ fentanyl \\
\hline & $\begin{array}{l}\text { Induction of anaesthesia: } 5 \mathrm{mg} / \mathrm{kg} \text { thiopental, } 0.1 \mathrm{mg} / \mathrm{kg} \text { vecuronium, } 1.5 \% \text { isoflurane, } 66 \% \text { nitrous ox- } \\
\text { ide in oxygen }\end{array}$ \\
\hline & Maintenance of anaesthesia: $0.8 \%$ isoflurane, $66 \%$ nitrous oxide in oxygen \\
\hline & Mean age: 35.55 years, $\mathrm{SD}=9.15$ (amino acids); 38 years, $\mathrm{SD}=13$ (normal saline) \\
\hline & Male/Female: 4/27 (amino acids); 6/26 (normal saline) \\
\hline \multirow[t]{2}{*}{ Interventions } & $\begin{array}{l}\text { Amino acid infusion }(\mathrm{n}=31) \text { : continuous infusion administered in a micro drip set at a rate of } 100 \mathrm{~mL} / \\
\mathrm{h} \text { through a separate dedicated IV line. Ringer's lactate was given at operating room temperature intra- } \\
\text { operatively for fluid replacement. }\end{array}$ \\
\hline & $\begin{array}{l}\text { Normal saline }(\mathrm{N}=32) \text { : continuous infusion administered in a micro drip set at a rate of } 100 \mathrm{~mL} / \mathrm{h} \\
\text { through a separate dedicated IV line. Ringer's lactate was given at operating room temperature intra- } \\
\text { operatively for fluid replacement. }\end{array}$ \\
\hline Outcomes & Nasopharynx temperature and surface temperature every 10 minutes $\left({ }^{\circ} \mathrm{C}\right)$ \\
\hline Notes & Source of funding was not reported. Conflicts of interest were not reported. \\
\hline
\end{tabular}

\section{Risk of bias}

\begin{tabular}{lll}
\hline Bias & Authors' judgement & Support for judgement \\
\hline $\begin{array}{l}\text { Random sequence genera- } \\
\text { tion (selection bias) }\end{array}$ & Low risk & States that this is a prospective randomized study \\
\hline $\begin{array}{l}\text { Allocation concealment } \\
\text { (selection bias) }\end{array}$ & Low risk & States that study was double-blind \\
\hline $\begin{array}{l}\text { Blinding of participants } \\
\begin{array}{l}\text { and personnel (perfor- } \\
\text { mance bias) }\end{array}\end{array}$ & Low risk & $\begin{array}{l}\text { Quotation: 'amino acid and saline solutions were prepared by a person not fur- } \\
\text { ther involved in the study' }\end{array}$ \\
\hline
\end{tabular}


Gupta 2006 (Continued)

All outcomes

\begin{tabular}{|c|c|c|}
\hline $\begin{array}{l}\text { Blinding of outcome as- } \\
\text { sessment (detection bias) }\end{array}$ & Low risk & States that study was double-blind \\
\hline
\end{tabular}

All outcomes

Incomplete outcome data Low risk No loss to follow-up
(attrition bias)

All outcomes

\begin{tabular}{lll}
\hline $\begin{array}{l}\text { Selective reporting (re- } \\
\text { porting bias) }\end{array}$ & Unclear risk & Not assessed \\
\hline Other bias & Low risk & No other concerns \\
\hline
\end{tabular}

\section{Gupta 2009}

\begin{tabular}{|c|c|}
\hline Methods & Single-centre trial conducted in India \\
\hline \multirow[t]{6}{*}{ Participants } & $\begin{array}{l}60 \text { adults ASA grade I/II (aged } 20 \text { to } 60 \text { years) scheduled for elective surgery under general anaesthesia. } \\
\text { Patients with known hepatic, neuromuscular, thyroid or renal disease; known allergy to study drug; re- } \\
\text { ceiving any drug known to affect neuromuscular transmission; and with } \mathrm{BMI}>30 \mathrm{~kg} / \mathrm{m}^{2} \text { were excluded } \\
\text { from the study. }\end{array}$ \\
\hline & Premedication: $2 \mathrm{mcg} / \mathrm{kg}$ fentanyl \\
\hline & $\begin{array}{l}\text { Induction of anaesthesia: } 5 \mathrm{mg} / \mathrm{kg} \text { thiopentone and, depending on allocation, either } 0.1 \mathrm{mg} / \mathrm{kg} \text { vecuro- } \\
\text { nium or } 0.5 \mathrm{mg} / \mathrm{kg} \text { atracurium besylate }\end{array}$ \\
\hline & Maintenance of anaesthesia: $0.8 \%$ isoflurane, $66 \%$ nitrous oxide in oxygen \\
\hline & $\begin{array}{l}\text { Mean age: } 41.18 \text { years, } S D=3.32 \text { (control + vecuronium); } 36.75 \text { years, } S D=9.66 \text { (amino acids + vecuroni- } \\
\text { um); } 33.53 \text { years, } S D=12.61 \text { (control + atracurium); } 34.27 \text { years, } S D=9.50 \text { (amino acids + atracurium) }\end{array}$ \\
\hline & $\begin{array}{l}\text { Male/Female: } 3 / 11 \text { (control + vecuronium); } 3 / 12 \text { (amino acids + vecuronium); 3/12 (control + atracuri- } \\
\text { um); } 1 / 14 \text { (amino acids + atracurium) }\end{array}$ \\
\hline \multirow[t]{5}{*}{ Interventions } & Control + vecuronium $(n=15)$ \\
\hline & Amino acids + vecuronium $(n=15)$ \\
\hline & Control + atracurium $(n=15)$ \\
\hline & Amino acids + atracurium $(n=15)$ \\
\hline & $\begin{array}{l}\text { All groups received a continuous infusion of amino acid solution or saline solution at the rate of } 100 \\
\mathrm{~mL} / \mathrm{h} \text { through a separate dedicated IV line before surgical incision, continued until reversal of the par- } \\
\text { ticipant from anaesthesia. Ringer's lactate at operating room temperature was given intraoperatively } \\
\text { for fluid replacement. }\end{array}$ \\
\hline
\end{tabular}

Outcomes Nasopharynx temperature

Notes

No useable outcomes, as time points at which data were recorded are unclear

Source of funding was not reported. Conflicts of interest were not reported.

\section{Risk of bias}


Gupta 2009 (Continued)

Bias Authors' judgement Support for judgement

\begin{tabular}{|c|c|c|}
\hline $\begin{array}{l}\text { Random sequence genera- } \\
\text { tion (selection bias) }\end{array}$ & Low risk & Quotation: 'prospective, randomised, double blind study' \\
\hline $\begin{array}{l}\text { Allocation concealment } \\
\text { (selection bias) }\end{array}$ & Unclear risk & Not stated \\
\hline $\begin{array}{l}\text { Blinding of participants } \\
\text { and personnel (perfor- } \\
\text { mance bias) } \\
\text { All outcomes }\end{array}$ & Low risk & Double-blind study \\
\hline $\begin{array}{l}\text { Blinding of outcome as- } \\
\text { sessment (detection bias) } \\
\text { All outcomes }\end{array}$ & Unclear risk & Unclear if outcome assessors were blinded \\
\hline $\begin{array}{l}\text { Incomplete outcome data } \\
\text { (attrition bias) } \\
\text { All outcomes }\end{array}$ & Low risk & No loss to follow-up \\
\hline $\begin{array}{l}\text { Selective reporting (re- } \\
\text { porting bias) }\end{array}$ & Unclear risk & Not assessed \\
\hline Other bias & Low risk & No other concerns \\
\hline
\end{tabular}

Kamitani 2006

\begin{tabular}{|c|c|}
\hline Methods & Single-centre prospective randomized trial conducted in Japan \\
\hline \multirow[t]{6}{*}{ Participants } & $\begin{array}{l}74 \text { patients ASA I-III scheduled for open gastrectomy with combined general and epidural anaesthesia } \\
\text { ( } 42 \text { patients with duration of surgery } 180 \text { minutes or longer; } 32 \text { patients with duration of surgery less } \\
\text { than } 180 \text { minutes) }\end{array}$ \\
\hline & $\begin{array}{l}\text { Premedication: All participants received oral midazolam }(3-5 \mathrm{mg}) 30 \text { minutes before entering the oper- } \\
\text { ation room (OR) and underwent epidural anaesthesia after entering the OR. }\end{array}$ \\
\hline & $\begin{array}{l}\text { Induction of anaesthesia: Anaesthesia was induced with propofol }(1-2 \mathrm{mg} / \mathrm{kg}) \text { and fentanyl }(1-2 \mathrm{mcg} / \\
\mathrm{kg}) \text {, and all participants were intubated after receiving vecuronium }(0.1-0.15 \mathrm{mg} / \mathrm{kg}) \text {. }\end{array}$ \\
\hline & $\begin{array}{l}\text { Maintenance of anaesthesia: Anaesthesia was maintained with oxygen }(0.7 \mathrm{~L} / \mathrm{min}) \text {, air }(2 \mathrm{~L} / \mathrm{min}) \text { and } \\
\text { sevoflurane at about } 1.5 \% \text {. }\end{array}$ \\
\hline & Mean age: 63.02 years, SD = 9.7 (amino acids); 65.35 years, SD = 4.68 (electrolytes) \\
\hline & Male/Female: 26/10 (amino acids); 30/8 (electrolytes) \\
\hline \multirow[t]{3}{*}{ Interventions } & Amino acids $(n=36): 200 \mathrm{~mL}$ administered for 1 hour from induction of anaesthesia \\
\hline & Electrolyte solution $(n=38): 200 \mathrm{~mL}$ for 1 hour from induction of anaesthesia \\
\hline & All participants received an additional heated mat. \\
\hline Outcomes & Tympanic temperature, incidence of hypothermia (core temperature $<35.5^{\circ} \mathrm{C}$ \\
\hline Notes & Translated from Japanese \\
\hline
\end{tabular}


Kamitani 2006 (Continued)

Risk of bias

\begin{tabular}{|c|c|c|}
\hline Bias & Authors' judgement & Support for judgement \\
\hline $\begin{array}{l}\text { Random sequence genera- } \\
\text { tion (selection bias) }\end{array}$ & Unclear risk & Not stated \\
\hline $\begin{array}{l}\text { Allocation concealment } \\
\text { (selection bias) }\end{array}$ & Unclear risk & Not stated \\
\hline $\begin{array}{l}\text { Blinding of participants } \\
\text { and personnel (perfor- } \\
\text { mance bias) } \\
\text { All outcomes }\end{array}$ & Unclear risk & Not stated \\
\hline $\begin{array}{l}\text { Blinding of outcome as- } \\
\text { sessment (detection bias) } \\
\text { All outcomes }\end{array}$ & Unclear risk & Not stated \\
\hline $\begin{array}{l}\text { Incomplete outcome data } \\
\text { (attrition bias) } \\
\text { All outcomes }\end{array}$ & Low risk & No loss to follow-up \\
\hline $\begin{array}{l}\text { Selective reporting (re- } \\
\text { porting bias) }\end{array}$ & Unclear risk & Not assessed \\
\hline Other bias & Low risk & No other concerns \\
\hline
\end{tabular}

Kanazawa 2008

\begin{tabular}{|c|c|}
\hline Methods & Single-centre trial conducted in Japan \\
\hline \multirow[t]{6}{*}{ Participants } & $\begin{array}{l}20 \text { patients ASA I/II scheduled to undergo surgery for posterior lumbar decompression and fusion un- } \\
\text { der general anaesthesia. Patients with cardiovascular disease, gastrointestinal disease, diabetes melli- } \\
\text { tus and hepatic or renal dysfunction were excluded. }\end{array}$ \\
\hline & Premedication: none \\
\hline & Induction of anaesthesia: propofol, fentanyl, vecuronium bromide \\
\hline & Maintenance of anaesthesia: oxygen, nitrous oxide and sevoflurane with a small dose of fentanyl \\
\hline & Mean age: 57.3 years, SD = 10.6 (amino acids + warm fluids); 50.1 years, SD = 17.3 (warm fluids only) \\
\hline & Male/Female: 9/1 (amino acids + warm fluids); 7/3 (warm fluids only) \\
\hline \multirow[t]{3}{*}{ Interventions } & $\begin{array}{l}\text { Amino acids + warm fluids }(n=10) \text { : After induction of anaesthesia, } 1 \% \text { acetated Ringer's solution was } \\
\text { administered with a fluid warmer (Hotline) set at } 41^{\circ} \mathrm{C} \text {. Following absence of eyelash reflex, a } 10 \% \\
\text { amino acid mixture (Amiparen) was administered intravenously at a dose of } 5 \mathrm{~mL} / \mathrm{kg} \text { over } 1 \text { hour. }\end{array}$ \\
\hline & $\begin{array}{l}\text { Warm fluids only }(n=10) \text { : After induction of anaesthesia, } 1 \% \text { acetated Ringer's solution was adminis- } \\
\text { tered with a fluid warmer (Hotline) set at } 41^{\circ} \mathrm{C}(10 \%) \text {. Following absence of eyelash reflex, saline was } \\
\text { administered intravenously at a dose of } 5 \mathrm{~mL} / \mathrm{kg} \text { over } 1 \text { hour. }\end{array}$ \\
\hline & After completion of measurements, forced air warming was used in all participants. \\
\hline
\end{tabular}


Kanazawa 2008 (Continued)

Notes Source of funding was not reported. Conflicts of interest were not reported.

\section{Risk of bias}

\begin{tabular}{|c|c|c|}
\hline Bias & Authors' judgement & Support for judgement \\
\hline $\begin{array}{l}\text { Random sequence genera- } \\
\text { tion (selection bias) }\end{array}$ & Low risk & Quotation: 'Patients were randomly divided into one of 2 groups' \\
\hline $\begin{array}{l}\text { Allocation concealment } \\
\text { (selection bias) }\end{array}$ & Unclear risk & Not stated \\
\hline $\begin{array}{l}\text { Blinding of participants } \\
\text { and personnel (perfor- } \\
\text { mance bias) } \\
\text { All outcomes }\end{array}$ & Unclear risk & Not stated \\
\hline $\begin{array}{l}\text { Blinding of outcome as- } \\
\text { sessment (detection bias) } \\
\text { All outcomes }\end{array}$ & Unclear risk & Not stated \\
\hline $\begin{array}{l}\text { Incomplete outcome data } \\
\text { (attrition bias) } \\
\text { All outcomes }\end{array}$ & Low risk & No loss to follow-up \\
\hline $\begin{array}{l}\text { Selective reporting (re- } \\
\text { porting bias) }\end{array}$ & Unclear risk & Not assessed \\
\hline Other bias & Low risk & No other concerns \\
\hline
\end{tabular}

Kasai 2003

\begin{tabular}{|c|c|}
\hline Methods & Single-centre trial conducted in Japan \\
\hline Participants & $\begin{array}{l}35 \text { patients aged } 20 \text { to } 65 \text { years scheduled to undergo peripheral surgery under spinal anaesthesia } \\
\text { Mean age: } 59 \text { years, range }=23 \text { to } 65 \text { (amino acids); } 55 \text { years, range }=20 \text { to } 65 \text { (saline) }\end{array}$ \\
\hline Interventions & $\begin{array}{l}\text { Amino acids }(n=18) \text { : Teruamino, a mixture of } 18 \text { amino acids, was given at a rate of } 2 \mathrm{~mL} / \mathrm{kg} 2 \text { hours be- } \\
\text { fore induction of spinal anaesthesia. } \\
\text { Saline }(n=17)\end{array}$ \\
\hline Outcomes & Core temperature, blood loss \\
\hline Notes & $\begin{array}{l}\text { None of the participants were obese or febrile, were receiving vasodilators or medications likely to alter } \\
\text { thermoregulation or had a history of thyroid disease or dysautonomia. } \\
\text { Source of funding was not reported. Conflicts of interest were not reported. }\end{array}$ \\
\hline
\end{tabular}

\section{Risk of bias}

\begin{tabular}{lll} 
Bias & Authors' judgement & Support for judgement \\
\hline $\begin{array}{l}\text { Random sequence genera- } \\
\text { tion (selection bias) }\end{array}$ & Low risk & $\begin{array}{l}\text { States that study was prospectively randomized: 'patients were assigned ran- } \\
\text { domly in two groups' }\end{array}$
\end{tabular}


Kasai 2003 (Continued)

\begin{tabular}{lll}
$\begin{array}{l}\text { Allocation concealment } \\
\text { (selection bias) }\end{array}$ & Low risk & States that study was double-blinded \\
\hline $\begin{array}{l}\text { Blinding of participants } \\
\text { and personnel (perfor- } \\
\text { mance bias) }\end{array}$ & Low risk & States that study was double-blinded \\
All outcomes & &
\end{tabular}

\begin{tabular}{lll}
\hline $\begin{array}{l}\text { Blinding of outcome as- } \\
\text { sessment (detection bias) } \\
\text { All outcomes }\end{array}$ & Low risk & States that study was double-blinded \\
\hline $\begin{array}{l}\text { Incomplete outcome data } \\
\begin{array}{l}\text { (attrition bias) } \\
\text { All outcomes }\end{array}\end{array}$ & Unclear risk & No loss to follow-up \\
\hline $\begin{array}{l}\text { Selective reporting (re- } \\
\text { porting bias) }\end{array}$ & Unclear risk & Not assessed \\
\hline Other bias & Low risk & No other concerns \\
\hline
\end{tabular}

\section{Mizobe 2006}

\begin{tabular}{|c|c|}
\hline Methods & Single-centre trial conducted in Japan \\
\hline Participants & 40 patients ASA I/II aged 29 to 61 years scheduled for open lower abdominal surgery \\
\hline \multirow[t]{3}{*}{ Interventions } & $\begin{array}{l}\text { Fructose infusion ( } \mathrm{n}=20 \text { overall, } \mathrm{n}=10 \text { for temperature outcomes): Fructon infusions were given ac- } \\
\text { cording to manufacturer instructions at a rate of } 0.5 \mathrm{~g} / \mathrm{kg} / \mathrm{h} \text { for } 4 \text { hours (starting } 3 \text { hours before induc- } \\
\text { tion of anaesthesia) using an electric infusion pump. }\end{array}$ \\
\hline & $\begin{array}{l}\text { Saline infusion ( } n=20 \text { overall, } n=10 \text { for temperature outcomes): Saline infusions were given at a rate } \\
\text { of } 0.5 \mathrm{~g} / \mathrm{kg} / \mathrm{h} \text { for } 4 \text { hours (starting } 3 \text { hours before induction of anaesthesia) using an electric infusion } \\
\text { pump. }\end{array}$ \\
\hline & $\begin{array}{l}\text { Each group was divided into } 2 \text { subgroups }(n=10) \text { : } 1 \text { for measurement of oesophageal temperature and } \\
1 \text { for oxygen consumption }\end{array}$ \\
\hline Outcomes & Core temperature, blood loss \\
\hline \multirow[t]{2}{*}{ Notes } & $\begin{array}{l}\text { None of the participants were obese or febrile, were receiving vasodilators or medications likely to alter } \\
\text { thermoregulation or had a history of thyroid disease or dysautonomia. }\end{array}$ \\
\hline & $\begin{array}{l}\text { Supported by grants from the National Institutes of Health; Gheens Foundation; Joseph Drown Foun- } \\
\text { dation; Commonwealth of Kentucky Research Challenge Trust Fund, Mallinckrodt Anesthesiology Prod- } \\
\text { ucts donated the thermocouples used in this study. None of the study authors had a financial relation- } \\
\text { ship with any company related to this research }\end{array}$ \\
\hline
\end{tabular}

\section{Risk of bias}

\begin{tabular}{lll}
\hline Bias & Authors' judgement & Support for judgement \\
\hline $\begin{array}{l}\text { Random sequence genera- } \\
\text { tion (selection bias) }\end{array}$ & Low risk & $\begin{array}{l}\text { Patients were allocated to treatment based on a 4 way randomization using } \\
\text { computer generated codes }\end{array}$ \\
\hline
\end{tabular}


Mizobe 2006 (Continued)

$\begin{array}{ll}\begin{array}{l}\text { Allocation concealment } \\ \text { (selection bias) }\end{array} \quad \text { Low risk } & \text { 'Randomisation codes were maintained in sequentially numbered envelopes } \\ \text { that were opened } 3 \text { hours before surgery' }\end{array}$

Blinding of participants Unclear risk Unclear if participants were blinded

and personnel (perfor-

mance bias)

All outcomes

Blinding of outcome as-
sessment (detection bias)

sessment (detection bias)

All outcomes

Incomplete outcome data Low risk No loss to follow-up
(attrition bias)

All outcomes

\begin{tabular}{lll}
\hline $\begin{array}{l}\text { Selective reporting (re- } \\
\text { porting bias) }\end{array}$ & Unclear risk & Not assessed \\
\hline Other bias & Low risk & No other concerns \\
\hline
\end{tabular}

\section{Mohamed 2005}

\begin{tabular}{|c|c|}
\hline Methods & Single-centre trial conducted in Egypt \\
\hline \multirow[t]{6}{*}{ Participants } & $\begin{array}{l}40 \text { patients ASA I/II undergoing major abdominal surgery for stomach cancer and hemicolectomy with } \\
\text { an expected duration of 3-5 hours. People with a core temperature }>37.2^{\circ} \mathrm{C} \text {; patients not expected to } \\
\text { withstand volume expansion (e.g. patients with mitral stenosis); patients with thyroid dysfunction, } \\
\text { end-stage renal failure, hepatic failure or major disease of the cardiovascular or respiratory system; } \\
\text { and patients who received drugs or parenteral infusions known to affect the basal metabolic rate or } \\
\text { body temperature within a week before the study were excluded. }\end{array}$ \\
\hline & Premedication: $0.03 \mathrm{mg} / \mathrm{kg}$ midazolam \\
\hline & Induction of anaesthesia: fentanyl $1 \mathrm{mcg} / \mathrm{kg}$, thiopental $4-5 \mathrm{mg} / \mathrm{kg}$, atracurium $0.4 \mathrm{mg} / \mathrm{kg}$ \\
\hline & Maintenance of anaesthesia: isoflurane $0.5-1.3 \mathrm{MAC}$ in $50 \%$ nitrous oxide \\
\hline & Mean age: 48 years, $S D=5($ Group $A) ; 50$ years, $S D=4($ Group $B)$ \\
\hline & Male/Female: not stated \\
\hline
\end{tabular}

Interventions Group A $(\mathrm{n}=20)$ : received IV amino acid infusion (Aminosteril) at a rate of $125 \mathrm{~mL} / \mathrm{h}$ for 1 hour before the operation, plus nutrient-free saline to complete fluid replacement for the participant

Group B $(n=20)$ : received IV nutrient-free saline according to the fluid requirement of the participant without amino acid infusion

All IV infusions, including amino acids and saline, were given at $37^{\circ} \mathrm{C}$.

\begin{tabular}{ll}
\hline Outcomes & Tympanic temperature, blood loss, shivering \\
\hline Notes & $\begin{array}{l}\text { People with a core temperature }>37.2^{\circ} \mathrm{C} \text {; patients not expected to withstand volume expansion (e.g. } \\
\text { patients with mitral stenosis); patients with thyroid dysfunction, end-stage renal failure, hepatic failure } \\
\text { or major disease of the cardiovascular or respiratory system; and patients who received drugs or par- } \\
\text { enteral infusions known to affect basal metabolic rate or body temperature within a week before the } \\
\text { study were excluded. }\end{array}$
\end{tabular}


Mohamed 2005 (Continued)

Source of funding was not reported. Conflicts of interest were not reported.

\section{Risk of bias}

\begin{tabular}{lll}
\hline Bias & Authors' judgement & Support for judgement \\
\hline $\begin{array}{l}\text { Random sequence genera- } \\
\text { tion (selection bias) }\end{array}$ & Low risk & Quotation: 'patients were randomly divided into two equal groups' \\
\hline $\begin{array}{l}\text { Allocation concealment } \\
\text { (selection bias) }\end{array}$ & Unclear risk & Not stated \\
\hline $\begin{array}{l}\text { Blinding of participants } \\
\text { and personnel (perfor- } \\
\text { mance bias) }\end{array}$ & Unclear risk & Not stated \\
All outcomes & \\
\hline $\begin{array}{l}\text { Blinding of outcome as- } \\
\text { sessment (detection bias) } \\
\text { All outcomes }\end{array}$ & Unclear risk & Not stated \\
\hline $\begin{array}{l}\text { Incomplete outcome data } \\
\text { (attrition bias) }\end{array}$ & Low risk & No loss to follow-up \\
\begin{tabular}{l} 
All outcomes \\
\hline $\begin{array}{l}\text { Selective reporting (re- } \\
\text { porting bias) }\end{array}$
\end{tabular} & Unclear risk & Not assessed \\
\hline \begin{tabular}{l} 
Other bias \\
\hline
\end{tabular} & Low risk & No other concerns \\
\hline
\end{tabular}

Negishi 2000

\begin{tabular}{ll}
\hline Methods & Single-centre trial conducted in Japan \\
\hline Participants & 24 patients undergoing elective abdominal surgery under combined general and epidural anaesthesia \\
& Premedication: not stated \\
Induction of anaesthesia: not stated \\
Maintenance of anaesthesia: continuous epidural and general anaesthesia with propofol and $60 \%$ ni- \\
trous oxide in oxygen \\
Mean age: not stated \\
Male/Female: not stated
\end{tabular}

Interventions

Control $(\mathrm{n}=$ not stated): no amino acids

AA 1 ( $n=$ not stated): intravenous amino acid infusion at $0.2 \mathrm{~g} / \mathrm{kg} / \mathrm{h}$ administered for 2 hours from induction of anaesthesia

AA 2 ( $n=$ not stated): intravenous amino acid infusion at $0.4 \mathrm{~g} / \mathrm{kg} / \mathrm{h}$ administered for 2 hours from induction of anaesthesia

AA $3(n=$ not stated): intravenous amino acid infusion at $0.6 \mathrm{~g} / \mathrm{kg} / \mathrm{h}$ administered for 2 hours from induction of anaesthesia 
Negishi 2000 (Continued)

Outcomes Tympanic temperature

\section{Risk of bias}

\begin{tabular}{|c|c|c|}
\hline Bias & Authors' judgement & Support for judgement \\
\hline $\begin{array}{l}\text { Random sequence genera- } \\
\text { tion (selection bias) }\end{array}$ & Low risk & States that random assignment was used \\
\hline $\begin{array}{l}\text { Allocation concealment } \\
\text { (selection bias) }\end{array}$ & Unclear risk & Not stated \\
\hline $\begin{array}{l}\text { Blinding of participants } \\
\text { and personnel (perfor- } \\
\text { mance bias) } \\
\text { All outcomes }\end{array}$ & Unclear risk & Not stated \\
\hline $\begin{array}{l}\text { Blinding of outcome as- } \\
\text { sessment (detection bias) } \\
\text { All outcomes }\end{array}$ & Unclear risk & Not stated \\
\hline $\begin{array}{l}\text { Incomplete outcome data } \\
\text { (attrition bias) } \\
\text { All outcomes }\end{array}$ & Unclear risk & Not stated \\
\hline $\begin{array}{l}\text { Selective reporting (re- } \\
\text { porting bias) }\end{array}$ & Unclear risk & Not assessed \\
\hline Other bias & Unclear risk & Abstract only; insufficient detail provided for assessment of other biases \\
\hline
\end{tabular}

\section{Sahin 2002}

\begin{tabular}{|c|c|}
\hline Methods & Single-centre trial conducted in Turkey \\
\hline \multirow[t]{7}{*}{ Participants } & 40 patients ASA I-III scheduled for elective supratentorial tumour excision \\
\hline & $\begin{array}{l}\text { Patients with tumours larger than } 3 \mathrm{~cm} \text { in diameter, patients with invasion to the mid-brain and hypo- } \\
\text { thalamus, hydrocephalic patients and patients with infratentorial tumours were excluded. }\end{array}$ \\
\hline & Premedication: none \\
\hline & Induction of anaesthesia: propofol $2 \mathrm{mg} / \mathrm{kg}$, fentanyl $1 \mathrm{mcg} / \mathrm{kg}$, vecuronium $0.1 \mathrm{mg} / \mathrm{kg}$ \\
\hline & $\begin{array}{l}\text { Maintenance of anaesthesia: All received fentanyl and nitrous oxide }\left(50 \% \text { in } \mathrm{O}_{2}\right) \text { and either isoflurane or } \\
\text { propofol as per the intervention groups below. }\end{array}$ \\
\hline & Mean age: not stated \\
\hline & Male/Female: $21 / 19$ \\
\hline
\end{tabular}

Interventions

Participants were randomized to 1 of 4 groups.

Isoflurane only $(n=10): 0.7 \%-1 \%$ isoflurane

Isoflurane plus amino acids $(\mathrm{n}=10): 0.7 \%-1 \%$ isoflurane and amino acids at $100 \mathrm{~kJ} / \mathrm{h}$ 
Sahin 2002 (Continued)

Propofol only $(n=10): 6-12 \mathrm{mg}^{\mathrm{kg}}-^{-1} \mathrm{~h}^{-1}$ propofol

Propofol plus amino acids $(n=10): 6-12 \mathrm{mg} \mathrm{kg}^{-1}{ }^{1} \mathrm{~h}-{ }^{1}$ propofol and amino acids at $100 \mathrm{~kJ} / \mathrm{h}$

\begin{tabular}{ll}
\hline Outcomes & Core temperature, shivering \\
\hline Notes & Source of funding was not reported. Conflicts of interest were not reported.
\end{tabular}

\section{Risk of bias}

Bias Authors' judgement Support for judgement

\begin{tabular}{ll}
\hline Random sequence genera- Low risk & Prospective randomized study \\
tion (selection bias)
\end{tabular}

tion (selection bias)

$\begin{aligned} & \text { Allocation concealment } \\ & \text { (selection bias) }\end{aligned}$
Unclear risk Not stated

\begin{tabular}{|c|c|c|}
\hline $\begin{array}{l}\text { Blinding of participants } \\
\text { and personnel (perfor- } \\
\text { mance bias) } \\
\text { All outcomes }\end{array}$ & Unclear risk & Not stated \\
\hline $\begin{array}{l}\text { Blinding of outcome as- } \\
\text { sessment (detection bias) } \\
\text { All outcomes }\end{array}$ & Unclear risk & $\begin{array}{l}\text { Shivering was assessed by an anaesthesiologist who was unaware of what the } \\
\text { participant received. }\end{array}$ \\
\hline
\end{tabular}

\begin{tabular}{lll}
\hline $\begin{array}{l}\text { Incomplete outcome data } \\
\text { (attrition bias) } \\
\text { All outcomes }\end{array}$ & Low risk & No loss to follow-up \\
\hline $\begin{array}{l}\text { Selective reporting (re- } \\
\text { porting bias) }\end{array}$ & Unclear risk & Not assessed \\
\hline Other bias & Low risk & No other concerns \\
\hline
\end{tabular}

Sellden 1999

Methods Single-centre trial conducted in Sweden. Paper states that patients included in this study were included in previous reports (Sellden 1994, Sellden 1996a, Sellden 1996b, Sellden 1998a). To avoid 'double-counting', we have treated these reports as 1 study; however, the number of patients included in Sellden 1999 is different from the numbers included in previous studies, and it is unclear why.

Some studies reported a factorial design in which more than 1 amino acid group was compared with a control group. In these cases, amino acid groups were pooled.

- Sellden 1994; 2 groups: Group 1 = amino acid infusion started immediately before and throughout surgery; Group 2 = saline solution administered (unclear when this was started)

- Sellden 1996a: 2 groups: Group 1 = amino acid infusion started immediately before and throughout surgery; Group 2 = saline solution administered (unclear when this was started)

- Sellden 1996b: 3 groups: Group 1 = amino acid infusion started 1 hour before anaesthesia and continued throughout surgery; Group 2 = amino acid infusion started 2 hours before anaesthesia and continued throughout surgery; Group 3 = saline solution infused 1 hour before and for 1 st hour of anaesthesia

- Sellden 1998a: 3 groups: Group 1 = amino acid infusion started during anaesthesia; Group 2 = amino acid infusion started 1 hour before anaesthesia, and for another 1.5 hours during anaesthesia and surgery; Group 3 = Ringer's solution started during anaesthesia 
Sellden 1999 (Continued)

- Sellden 1999: 2 groups: Group 1 = amino acid infusion started with induction of anaesthesia until awakening; Group 2 = saline solution administered for the same time period
Participants scheduled for abdominal surgery, ASA I

Premedication: lorazopam 1-3 mg (except in 3 patients, who were given ketobemidone $5 \mathrm{mg}$ )

Induction of anaesthesia: thiopentone $5 \mathrm{mg} / \mathrm{kg}$

Maintenance of anaesthesia: enflurane or isoflurane in $40 \%$ oxygen, $60 \%$ nitrous oxide. Muscle relaxation was achieved with atracurium as a continuous infusion of $0.5 \mathrm{mg} / \mathrm{kg} / \mathrm{h}$ after an initial bolus dose of $0.5 \mathrm{mg} / \mathrm{kg}$ was given. Before surgery was started, fentanyl $(3 \mathrm{mcg} / \mathrm{kg})$ was given.

- Sellden 1994: 21 males

- Sellden 1996a: 14 males

- Sellden 1996b: 24 females

- Sellden 1998a: 24 females

- Sellden 1999: 75 (27 males and 48 females)
Amino acids: A mixture of 19 amino acids (Vamin) was infused at a rate of $126 \mathrm{~mL} / \mathrm{h}$ before and/or during anaesthesia ( 1 hour before and continuing for 1 hour $(n=8)$, or 1.5 hours $(n=8)$, into anaesthesia and surgery $(n=8)$, or for 2.5 hours during anaesthesia and surgery $(n=21)$ ).

Control: nutrient-free acetated Ringer's solution

In all participants, nutrient-free acetated Ringer's solution was infused at $500 \mathrm{~mL} / \mathrm{h}$ during surgery.

- Sellden 1994: amino acids $N=10$, control $N=11$

- Sellden 1996a: amino acids $N=7$, control $N=7$

- Sellden 1996b: amino acids $N=16$, control $N=8$

- Sellden 1998a: amino acids $N=16$, control $N=8$

- Sellden 1999: amino acids $N=45$, control $N=30$

Temperature, shivering, length of hospital stay
- Sellden 1994: core temperature (Analysis 1.3), shivering
- Sellden 1996a: core temperature, shivering
- Sellden 1996b: core temperature, shivering
- Sellden 1998a: core temperature (Analysis 1.1, Analysis 1.2), shivering
- Sellden 1999: core temperature, shivering (Analysis 1.4), length of stay

Notes

2 participants received warmed blood (1 control and 1 amino acid)

Study was supported by the Swedish Medical Research Council, The Swedish Society for Medical Research and Forenade Liv Mutual Group Life Insurance Company. Conflicts of interest were not reported.

\section{Risk of bias}

\begin{tabular}{lll}
\hline Bias & Authors' judgement & Support for judgement \\
\hline $\begin{array}{l}\text { Random sequence genera- } \\
\text { tion (selection bias) }\end{array}$ & Low risk & $\begin{array}{l}\text { Every second participant who agreed to participate was assigned to receive } \\
\text { amino acids. }\end{array}$ \\
\hline $\begin{array}{l}\text { Allocation concealment } \\
\text { (selection bias) }\end{array}$ & High risk & Alternation \\
\hline $\begin{array}{l}\text { Blinding of participants } \\
\begin{array}{l}\text { and personnel (perfor- } \\
\text { mance bias) }\end{array}\end{array}$ & Unclear risk & $\begin{array}{l}\text { Quotation: 'the patients, nurses and surgeons were unaware of whether amino } \\
\text { acids or Ringer's solution was given. Otherwise the study was not blinded'; 'At- } \\
\text { tending surgeons, unaware of the patients group assignment and core temper- }\end{array}$
\end{tabular}


Sellden 1999 (Continued)

All outcomes ature, determined when to begin oral feeding, remove sutures and discharge from the hospital'

\begin{tabular}{|c|c|c|}
\hline $\begin{array}{l}\text { Blinding of outcome as- } \\
\text { sessment (detection bias) } \\
\text { All outcomes }\end{array}$ & Unclear risk & Not stated \\
\hline $\begin{array}{l}\text { Incomplete outcome data } \\
\text { (attrition bias) } \\
\text { All outcomes }\end{array}$ & Unclear risk & No loss to follow-up \\
\hline $\begin{array}{l}\text { Selective reporting (re- } \\
\text { porting bias) }\end{array}$ & Unclear risk & Not assessed \\
\hline Other bias & Low risk & No other concerns \\
\hline
\end{tabular}

Widman 2002

\begin{tabular}{|c|c|c|}
\hline Methods & \multicolumn{2}{|c|}{ Single-centre trial conducted in Sweden } \\
\hline \multirow[t]{6}{*}{ Participants } & \multicolumn{2}{|c|}{$\begin{array}{l}46 \text { patients scheduled for primary hip arthroplasty under spinal anaesthesia. They were otherwise } \\
\text { healthy with no history of bleeding disorders and were receiving no medication except anti-inflamma- } \\
\text { tory and analgesic drugs for their hip problems. }\end{array}$} \\
\hline & \multicolumn{2}{|c|}{ Premedication: diazepam 5 mg } \\
\hline & \multicolumn{2}{|c|}{$\begin{array}{l}\text { Induction of anaesthesia: isobaric bupivacaine } 17 \pm 0.2 \mathrm{mg} \text {. Some participants ( } 18 \text { amino acid and } 17 \\
\text { control) received sedative drugs in small doses as a complement to the spinal anaesthesia (average } 100 \\
\mathrm{mg} \text { propofol). }\end{array}$} \\
\hline & \multicolumn{2}{|c|}{ Maintenance of anaesthesia: not stated } \\
\hline & \multicolumn{2}{|c|}{ Mean age: 67 years, $S D=7$ (amino acids); 67 years, $S D=6$ (control) } \\
\hline & \multicolumn{2}{|c|}{ Male/Female: 11/11 (amino acids); 12/12 (control) } \\
\hline Interventions & \multicolumn{2}{|c|}{$\begin{array}{l}\text { Amino acids ( } n=22 \text { ): A mixture of } 19 \text { amino acids (Vamin) was infused at a rate of } 126 \mathrm{~mL} / \mathrm{h} \text { starting } 1 \\
\text { hour before anaesthesia, continued throughout anaesthesia and completed at the end of surgery. }\end{array}$} \\
\hline & \multicolumn{2}{|c|}{ Control $(n=24)$ : corresponding volumes of acetated Ringer's solution } \\
\hline Outcomes & \multicolumn{2}{|c|}{ Temperature, blood loss } \\
\hline Notes & \multicolumn{2}{|c|}{$\begin{array}{l}\text { Supported by grants from The Stockholm County Council, Public Helath and Medical Science, Depart- } \\
\text { ment of Research Development and Teaching. Conflicts of interest were not reported. }\end{array}$} \\
\hline \multicolumn{3}{|l|}{ Risk of bias } \\
\hline Bias & Authors' judgement & Support for judgement \\
\hline $\begin{array}{l}\text { Random sequence genera- } \\
\text { tion (selection bias) }\end{array}$ & Low risk & $\begin{array}{l}\text { Quotation: 'The randomisation procedure was composed of sealed envelopes, } \\
24 \text { for men and } 24 \text { for women, marked for either amino acids or Ringer's infu- } \\
\text { sion. Each envelope was opened just before the study procedure' }\end{array}$ \\
\hline $\begin{array}{l}\text { Allocation concealment } \\
\text { (selection bias) }\end{array}$ & Low risk & Sealed envelopes \\
\hline
\end{tabular}


Widman 2002 (Continued)

Blinding of participants Low risk_ 'Neither the surgeon [nor] the patient was aware which infusion the patient reand personnel (perforceived. the infusion bag was covered with a small opaque sheet' mance bias)

All outcomes

\begin{tabular}{lll}
\hline $\begin{array}{l}\text { Blinding of outcome as- } \\
\text { sessment (detection bias) } \\
\text { All outcomes }\end{array}$ & Unclear risk & Not stated \\
\hline $\begin{array}{l}\text { Incomplete outcome data } \\
\begin{array}{l}\text { (attrition bias) } \\
\text { All outcomes }\end{array}\end{array}$ & Low risk & $\begin{array}{l}\text { Quotation: 'Two patients from the amino acids group were excluded because } \\
\text { of incomplete records' }\end{array}$ \\
\hline $\begin{array}{l}\text { Selective reporting (re- } \\
\text { porting bias) }\end{array}$ & Unclear risk & Not assessed \\
\hline \begin{tabular}{l} 
Other bias \\
\hline
\end{tabular} & Low risk & No other concerns \\
\hline
\end{tabular}

Zhong 2012

\begin{tabular}{|c|c|}
\hline Methods & Single-centre trial conducted in China \\
\hline \multirow[t]{6}{*}{ Participants } & $\begin{array}{l}36 \text { patients aged } 18 \text { to } 64 \text { years, ASA I/II, undergoing gastrointestinal surgery (stomach and colorectal) } \\
\text { under combined general anaesthesia and epidural block }\end{array}$ \\
\hline & Premedication: none \\
\hline & $\begin{array}{l}\text { Induction of anaesthesia: fentanyl } 3 \mathrm{mcg} / \mathrm{kg} \text { and propofol } 2 \mathrm{mg} / \mathrm{kg} \text {. Tracheal intubation was facilitated } \\
\text { by succinylcholine } 1.5 \mathrm{mg} / \mathrm{kg} \text {, and lungs were ventilated with } 40 \% \text { oxygen enriched with air. }\end{array}$ \\
\hline & $\begin{array}{l}\text { Maintenance of anaesthesia: } 6-10 \mathrm{~mL} \text { bupivacaine } 0.375 \% \text { was administered in increments and main- } \\
\text { tained with intermittent boluses of } 3-5 \mathrm{~mL} \text { every hour during the operation. General anaesthesia was } \\
\text { maintained with sevoflurane at an end-tidal concentration of } 1-2 \text { vol\%, changing with haemodynamic } \\
\text { monitoring. Supplemental doses of vecuronium were given to achieve muscle relaxation throughout } \\
\text { the operation. }\end{array}$ \\
\hline & Mean age: 53.4 years, $\mathrm{SD}=6.6($ amino acids); 51.1 years, $\mathrm{SD}=8.0$ (control) \\
\hline & Male/Female: 9/9 (amino acids); 10/8 (control) \\
\hline \multirow[t]{2}{*}{ Interventions } & Amino acids ( $\mathrm{n}=18$ ): 18 amino acids (Novamin) infused at a rate of $2 \mathrm{~mL} / \mathrm{kg} / \mathrm{h}$ \\
\hline & Control $(n=18)$ : lactated Ringer's solution delivered at the same rate \\
\hline Outcomes & Temperature \\
\hline \multirow[t]{2}{*}{ Notes } & $\begin{array}{l}\text { Participants were excluded if they had evidence of metastatic disease, hepatic or renal disease and di- } \\
\text { abetes; had a serum albumin }<35 \mathrm{~g} / \mathrm{L} \text { or anaemia; or were receiving drugs known to have metabolic ef- } \\
\text { fects such as corticosteroids or beta blockers. }\end{array}$ \\
\hline & Study authors received no funding and declared no conflicts of interest. \\
\hline
\end{tabular}

\section{Risk of bias}

Bias Authors' judgement Support for judgement


Zhong 2012 (Continued) $\begin{array}{ll}\begin{array}{l}\text { Random sequence genera- } \\ \text { tion (selection bias) }\end{array} & \text { Low risk } \\ \end{array}$

\begin{tabular}{|c|c|c|}
\hline $\begin{array}{l}\text { Allocation concealment } \\
\text { (selection bias) }\end{array}$ & Low risk & Sealed envelope \\
\hline $\begin{array}{l}\text { Blinding of participants } \\
\text { and personnel (perfor- } \\
\text { mance bias) } \\
\text { All outcomes }\end{array}$ & Low risk & $\begin{array}{l}\text { Quotation: 'Amino acids and lactated Ringer's solution were prepared by a } \\
\text { specific investigator, while other investigators and patients were all blinded to } \\
\text { the preparation' }\end{array}$ \\
\hline
\end{tabular}

\begin{tabular}{|c|c|c|}
\hline $\begin{array}{l}\text { Blinding of outcome as- } \\
\text { sessment (detection bias) } \\
\text { All outcomes }\end{array}$ & Low risk & Investigators were blinded. \\
\hline $\begin{array}{l}\text { Incomplete outcome data } \\
\text { (attrition bias) } \\
\text { All outcomes }\end{array}$ & Low risk & No loss to follow-up \\
\hline $\begin{array}{l}\text { Selective reporting (re- } \\
\text { porting bias) }\end{array}$ & Unclear risk & Not assessed \\
\hline Other bias & Low risk & No other concerns \\
\hline
\end{tabular}

$\mathrm{AA}=$ amino acids

ASA = American Society of Anesthesiologists

$\mathrm{BMI}=$ body mass index

$\mathrm{h}=$ hour

IV = intravenous

$\mathrm{kJ}=$ kilojoule

$\mathrm{N}, \mathrm{n}=$ number

$\mathrm{OR}=$ operating room

$\mathrm{SD}=$ standard deviation

$\mathrm{SE}=$ standard error

$y=$ year

Characteristics of excluded studies [ordered by study ID]

\begin{tabular}{ll}
\hline Study & Reason for exclusion \\
\hline Aoki 2015 & Study translation showed the description as non-randomized \\
\hline Baker 1984 & No control group was used \\
\hline Carlson 1994 & Investigators did not evaluate participants undergoing surgery \\
\hline Chandrasekaran 2004 & Participants were not randomized \\
\hline Donmez 1997 & Participants were not randomized \\
\hline Fujita 2012 & No control group was included. All groups received amino acids \\
\hline Hyltander 1993 & Intravenous nutrition was started 1 day after surgery \\
\hline Ignaki 2003 & Investigators did not evaluate participants undergoing surgery \\
\hline
\end{tabular}




\begin{tabular}{ll}
\hline Study & Reason for exclusion \\
\hline Inoue 2011 & Interventions were applied to treat patients with hypothermia \\
\hline Kamitani 2005 & $\begin{array}{l}\text { Investigators did not evaluate a nutritional intervention (nutrition is a side effect of the anaesthetic } \\
\text { carrier) }\end{array}$ \\
\hline Ohe 2014 & This was not a randomized (or quasi-randomized) trial \\
\hline
\end{tabular}

\section{DATA AND ANALYSES}

\section{Comparison 1. Amino acids vs no amino acids}

\begin{tabular}{lllll}
\hline Outcome or subgroup title & No. of studies & $\begin{array}{l}\text { No. of partici- } \\
\text { pants }\end{array}$ & Statistical method & Effect size \\
\hline $\begin{array}{l}1 \text { Mean core temperature, } 60 \\
\text { minutes }\end{array}$ & 9 & & $\begin{array}{l}\text { Mean Difference (IV, Random, 95\% } \\
\text { Cl) }\end{array}$ & Totals not selected \\
\hline $\begin{array}{l}\text { 2 Mean core temperature, } 120 \\
\text { minutes }\end{array}$ & 10 & 249 & $\begin{array}{l}\text { Mean Difference (IV, Random, 95\% } \\
\text { Cl) }\end{array}$ & Totals not selected \\
\hline $\begin{array}{l}\text { 3 Mean core temperature at } \\
\text { end of surgery }\end{array}$ & 6 & Mean Difference (IV, Random, 95\% & $0.46[0.33,0.59]$ \\
\hline $\begin{array}{l}\text { 4 Shivering } \\
\text { Cl) }\end{array}$ & 155 & Risk Ratio (M-H, Random, 95\% CI) & $0.36[0.13,1.00]$ \\
\hline
\end{tabular}

Analysis 1.1. Comparison 1 Amino acids vs no amino acids, Outcome 1 Mean core temperature, 60 minutes.

\begin{tabular}{|c|c|c|c|c|c|c|}
\hline \multirow[t]{2}{*}{ Study or subgroup } & \multicolumn{2}{|c|}{ Amino acids } & \multicolumn{2}{|c|}{ Control } & \multirow{2}{*}{$\begin{array}{l}\text { Mean Difference } \\
\text { Random, } 95 \% \mathrm{CI}\end{array}$} & \multirow{2}{*}{$\begin{array}{l}\text { Mean Difference } \\
\text { Random, } 95 \% \mathrm{Cl}\end{array}$} \\
\hline & $\mathbf{N}$ & Mean(SD) & $\mathbf{N}$ & Mean(SD) & & \\
\hline Fujita 2014 & 14 & $36.3(0.5)$ & 7 & $35.9(0.4)$ & 1 & $0.37[-0.01,0.75]$ \\
\hline Gupta 2006 & 30 & $36(0.5)$ & 32 & $35.8(0.4)$ & + & $0.2[-0.03,0.43]$ \\
\hline Kamitani 2006 & 36 & $-0.3(0.3)$ & 38 & $-0.3(0.3)$ & + & $-0.06[-0.19,0.07]$ \\
\hline Kanazawa 2008 & 10 & $35.7(0.5)$ & 10 & $35.5(0.6)$ & 1 & $0.2[-0.28,0.68]$ \\
\hline Kasai 2003 & 18 & $36.5(0.4)$ & 17 & $36(0.4)$ & $\longrightarrow$ & $0.5[0.22,0.78]$ \\
\hline Mohamed 2005 & 20 & $37(0.2)$ & 20 & $36.1(0.1)$ & + & $0.9[0.8,1]$ \\
\hline Sahin 2002 & 20 & $36.1(0.5)$ & 20 & $36.4(0.9)$ & 1 & $-0.3[-0.74,0.14]$ \\
\hline Sellden 1999 & 7 & $-0.9(0.3)$ & 8 & $-1.4(0.1)$ & + & $0.45[0.21,0.69]$ \\
\hline Widman 2002 & 22 & $-0.1(0.5)$ & 24 & $-0.4(0.5)$ & - & $0.3[0.02,0.58]$ \\
\hline
\end{tabular}


Analysis 1.2. Comparison 1 Amino acids vs no amino acids, Outcome 2 Mean core temperature, 120 minutes.

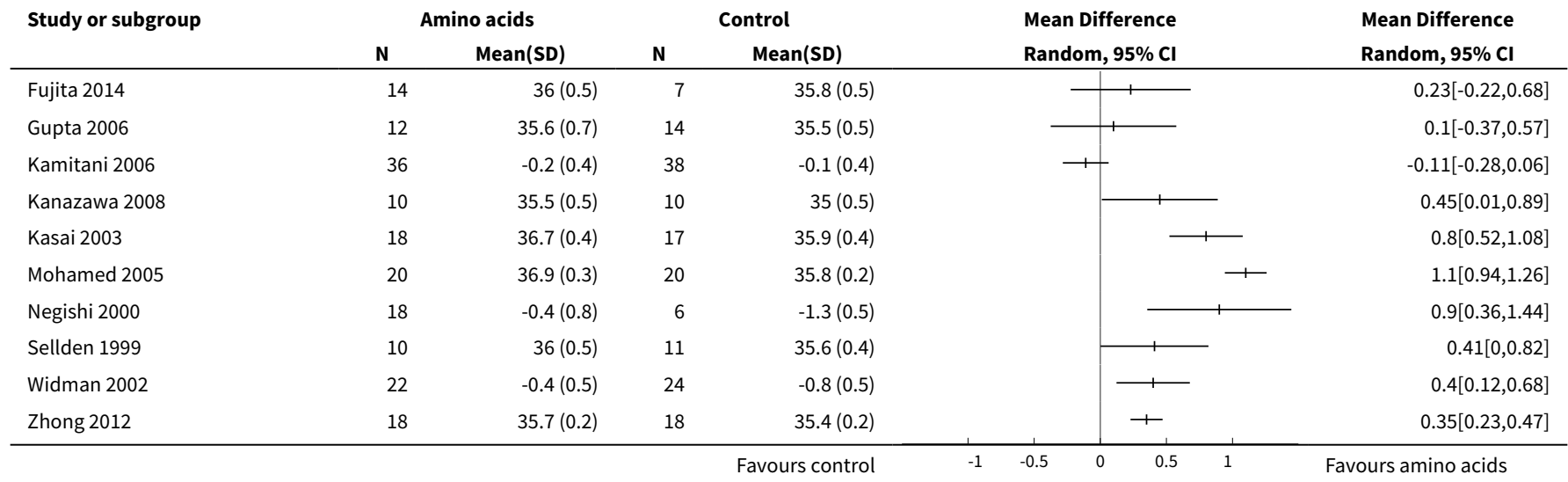

Analysis 1.3. Comparison 1 Amino acids vs no amino acids, Outcome 3 Mean core temperature at end of surgery.

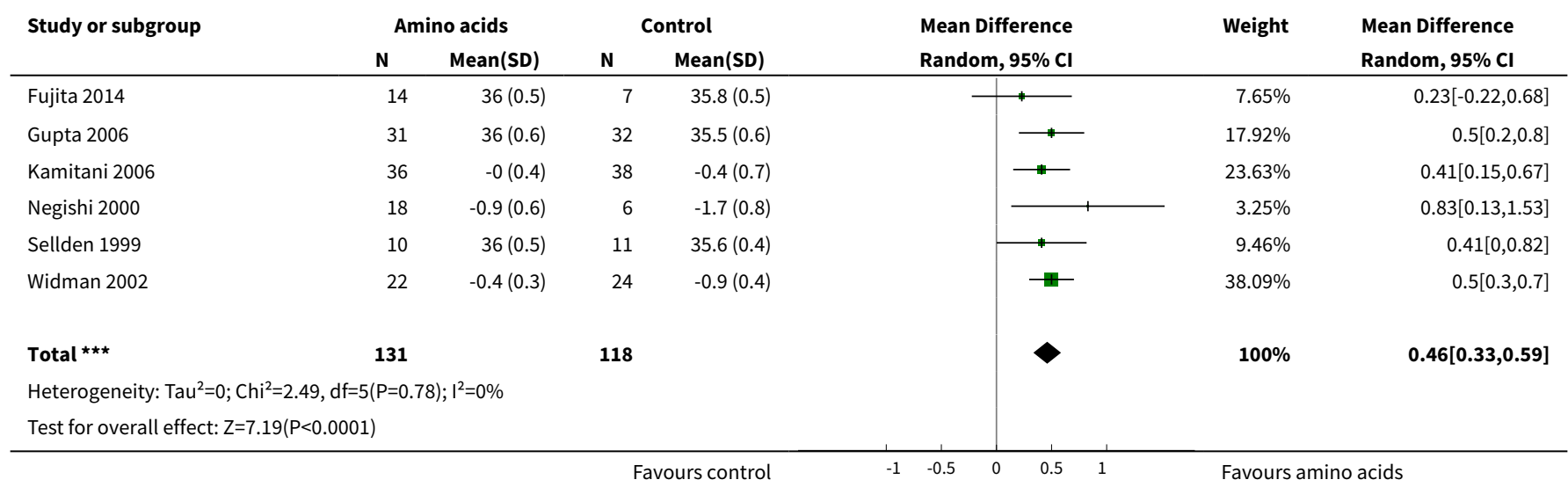

Analysis 1.4. Comparison 1 Amino acids vs no amino acids, Outcome 4 Shivering.

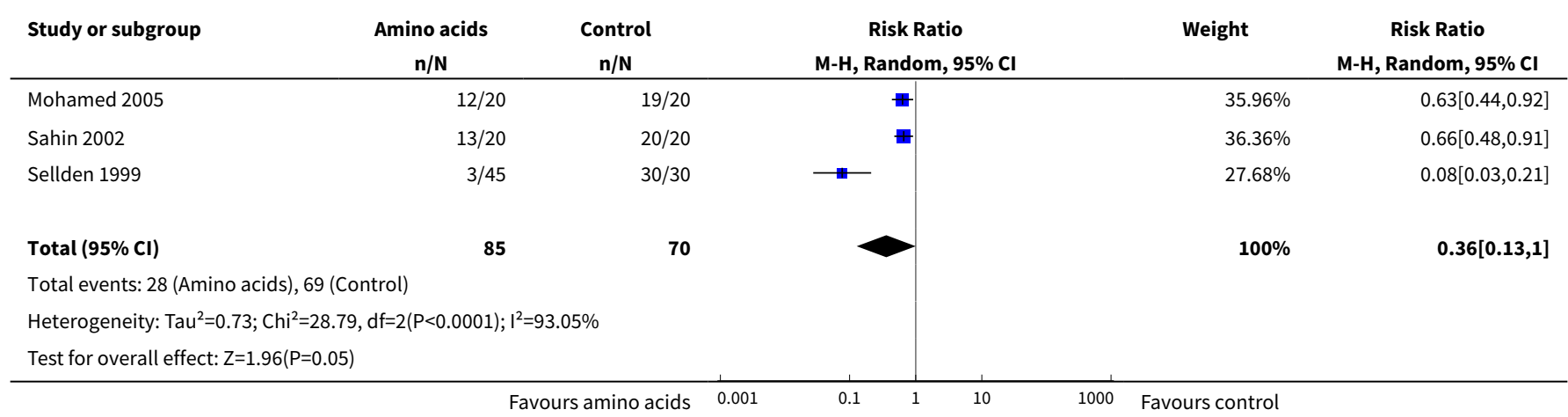




\section{AP P E N DICES}

\section{Appendix 1. Search strategy for CENTRAL, the Cochrane Library}

\#1MeSH descriptor: [Hypothermia] explode all trees

\#2MeSH descriptor: [Body Temperature Regulation] explode all trees

\#3MeSH descriptor: [Piloerection] explode all trees

\#4MeSH descriptor: [Shivering] explode all trees

\#5hypo?therm*or normo?therm* ${ }^{\star}$ or thermo?regulat* or shiver $^{\star}$ or ((thermal or temperature) near/2 (regulat ${ }^{\star}$ or manage* or maintain $\left.{ }^{\star}\right)$ ) or (low ${ }^{\star}$ near/2 temperature $\left.{ }^{\star}\right)$ or thermo?genesis or ((reduc ${ }^{\star}$ or prevent $\left.{ }^{\star}\right)$ and (temperature near/3 (decrease or decline))) or (heat near/2 (preserv* or loss or retention or retain ${ }^{\star}$ or balance)) or (core near/2 (thermal or temperature $\left.{ }^{\star}\right)$ )

\#6intravenous* or infusion* or IV or parenteral

$\# 7$ (\#1 or \#2 or \#3 or \#4 or \#5) and \#6

\#8MeSH descriptor: [Amino Acids] explode all trees

\#9nutrient* or amino acid ${ }^{\star}$ or fat ${ }^{\star}$ or glucose* or fructose* or electrolyte* or trace element* or vitamin ${ }^{\star}$ or Aminoplasmal ${ }^{\star}$ or Aminoven* or Clinimix ${ }^{\star}$ or ClinOleic* or Glamin* or Hyperamine* or Intralipid* or Kabiven* or Lipidem* or Lipfundin* or Nutriflex* or Nu TRIflex* or OliClinomel $^{\star}$ or Omegaven* or Plasma-Lyte* or Primene* or SMOFlipid ${ }^{\star}$ or StructoKabiven* or Structolipid ${ }^{\star}$ or Synthamin* or Vamin ${ }^{\star}$ or Vaminolact*

\#10\#8 or \#9

$\# 11 \# 7$ and \#10

\section{Appendix 2. Search strategy for MEDLINE (Ovid SP)}

\#1 ((randomized controlled trial or controlled clinical trial).pt. or randomized.ab. or placebo.ab. or drug therapy.fs. or randomly.ab. or trial.ab. or groups.ab.) not (animals not (humans and animals)).sh.

\#2 exp Hypothermia/ or exp body temperature regulation/ or exp piloerection/ or exp shivering/ or hypo?therm.af. or normo? therm*.mp. or thermo?regulat ${ }^{\star} . m p$. or shiver ${ }^{\star} . m p$. or ((thermal or temperature) adj2 (regulat* or manage* or maintain $\left.{ }^{\star}\right)$ ).mp. or (low ${ }^{\star}$ adj2 temperature $\left.{ }^{\star}\right) . m p$. or thermo?genesis.mp. or ((reduc ${ }^{\star}$ or prevent $\left.^{\star}\right)$.af. and (temperature adj3 (decrease or decline)).mp.) or (heat adj2 (preserv ${ }^{\star}$ or loss or retention or retain ${ }^{\star}$ or balance)).mp. or (core adj2 (thermal or temperature*)).mp.

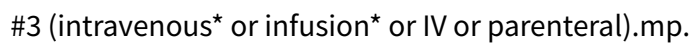

\#4 exp Amino Acids/ or (nutrient* or amino acid* or fat* or glucose* or fructose* or electrolyte ${ }^{\star}$ or trace element ${ }^{\star}$ or vitamin $^{\star}$ or (Aminoplasmal* or Aminoven* or Clinimix* or ClinOleic* or Glamin* or Hyperamine* or Intralipid* or Kabiven* or Lipidem* or Lipfundin*

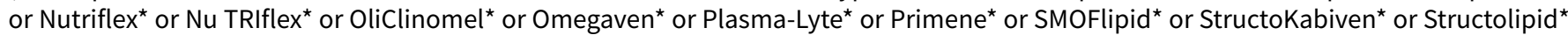
or Synthamin* or Vamin* or Vaminolact*)).mp.

\#5 \#3 and \#4

\#6 \#1 and \#2 and \#5

\section{Appendix 3. Search strategy for Embase (Ovid SP)}

\#1 (randomized-controlled-trial/or randomization/or controlled-study/or multicenter-study/or phase-3-clinical-trial/or phase-4-clinicaltrial/ or double-blind-procedure/ or single-blind-procedure/ or (random* or cross?over ${ }^{\star}$ or factorial* or placebo* or volunteer ${ }^{\star}$ or ((singl ${ }^{\star}$ or doubl* or trebl* or tripl*) adj3 (blind* or mask $\left.\left.{ }^{\star}\right)\right)$ ).ti,ab.) not (animals not (humans and animals)).sh.

\#2 exp Hypothermia/ or exp body temperature regulation/ or exp piloerection/ or exp shivering/ or hypo?therm.af. or normo? therm ${ }^{\star} . \mathrm{mp}$. or thermo?regulat*.mp. or shiver*.mp. or ((thermal or temperature) adj2 (regulat* or manage* or maintain $\left.{ }^{\star}\right)$ ).mp. or (low ${ }^{\star}$ adj2 temperature $\left.{ }^{\star}\right)$.mp. or thermo?genesis.mp. or ((reduc* or prevent $\left.{ }^{\star}\right)$.af. and (temperature adj3 (decrease or decline)).mp.) or (heat adj2 (preserv ${ }^{\star}$ or loss or retention or retain ${ }^{\star}$ or balance)).mp. or (core adj2 (thermal or temperature $\left.{ }^{\star}\right)$ ).mp.

\#3 (intravenous* or infusion* or IV or parenteral).mp.

\#4 exp Amino Acids/ or (nutrient* or amino acid* or fat* or glucose* or fructose* or electrolyte* or trace element* or vitamin* or (Aminoplasmal ${ }^{\star}$ or Aminoven ${ }^{\star}$ or Clinimix ${ }^{\star}$ or ClinOleic ${ }^{\star}$ or Glamin ${ }^{\star}$ or Hyperamine ${ }^{\star}$ or Intralipid ${ }^{\star}$ or Kabiven ${ }^{\star}$ or Lipidem ${ }^{\star}$ or Lipfundin $^{\star}$ or Nutriflex* or Nu TRIflex* or OliClinomel ${ }^{\star}$ or Omegaven* or Plasma-Lyte* or Primene ${ }^{\star}$ or SMOFlipid* or StructoKabiven* or Structolipid ${ }^{\star}$ or Synthamin* or Vamin* or Vaminolact $\left.\left.{ }^{\star}\right)\right) . m p$.

\#5 \#3 and \#4

\#6 \#1 and \#2 and \#5 


\section{Appendix 4. Search strategy for ISI Web of Science}

TOPIC: ((intravenous* ${ }^{\star}$ or infusion ${ }^{\star}$ or IV or parenteral) and (nutrient ${ }^{\star}$ or amino acid $^{\star}$ or fat ${ }^{\star}$ or glucose or fructose $^{\star}$ or electrolyte* or trace element ${ }^{\star}$ or vitamin* or (Aminoplasmal* or Aminoven* or Clinimix* or ClinOleic* or Glamin* or Hyperamine* or Intralipid ${ }^{\star}$ or Kabiven ${ }^{\star}$ or Lipidem* ${ }^{\star}$ or Lipfundin* or Nutriflex* or Nu TRIflex* or OliClinomel ${ }^{\star}$ or Omegaven* or Plasma-Lyte* or Primene* or SMOFlipid ${ }^{\star}$ or StructoKabiven* or Structolipid* or Synthamin* or Vamin* or Vaminolact*))) AND TOPIC: ((hypo?therm* or normo?therm* or thermo? regulat $^{\star}$ or shiver $\left.{ }^{\star}\right)$ or ((thermal or temperature) SAME (regulat* or manage ${ }^{\star}$ or maintain $\left.\left.{ }^{\star}\right)\right)$ or (low ${ }^{\star}$ SAME temperature ${ }^{\star}$ ) or thermo?genesis or ((reduc* or prevent $\left.{ }^{\star}\right)$ and temperature and (decrease or decline)) or (heat SAME (preserv* or loss or retention or retain ${ }^{\star}$ or balance)) or (core SAME (thermal or temperature $\left.\left.{ }^{\star}\right)\right)$ AND TOPIC: $\left(\right.$ random $^{\star}$ or (trial ${ }^{\star}$ SAME (control* or clinical $\left.{ }^{\star}\right)$ ) or placebo* or multicenter ${ }^{\star}$ or prospective $^{\star}$ or ((blind ${ }^{\star}$ or mask $\left.{ }^{\star}\right)$ SAME (single or double or triple or treble)))

\section{Appendix 5. Search strategy for CINAHL (EBSCO host)}

\section{S27 S12 AND S21 AND S26}

\section{S26 S24 AND S25}

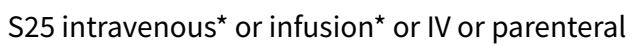

\section{S24 S22 OR S23}

S23 nutrient ${ }^{\star}$ or amino acid ${ }^{\star}$ or fat ${ }^{\star}$ or glucose ${ }^{\star}$ or fructose ${ }^{\star}$ or electrolyte* or trace element ${ }^{\star}$ or vitamin ${ }^{\star}$ or (Aminoplasmal ${ }^{\star}$ or Aminoven ${ }^{\star}$ or Clinimix ${ }^{\star}$ or ClinOleic ${ }^{\star}$ or Glamin* or Hyperamine or Intralipid $^{\star}$ or Kabiven* or Lipidem* or Lipfundin* or Nutriflex* or Nu TRIflex* or OliClinomel* or Omegaven* or Plasma-Lyte* or Primene* or SMOFlipid ${ }^{\star}$ or StructoKabiven* or Structolipid* or Synthamin* or Vamin* or Vaminolact ${ }^{\star}$ )

\section{S22 (MH "Amino Acids")}

\section{S21 S13 OR S14 OR S15 OR S16 OR S17 OR S18 OR S19 OR S20}

S20 core N3 (thermal or temperature*)

S19 heat N3 (preserv* or loss or retention or retain* or balance)

S18 thermogenesis

S17 ( reduc ${ }^{\star}$ or prevent ${ }^{\star}$ ) and temperature and (decrease or decline )

S16 low* N3 temperature*

S15 AB ((thermal or temperature) and (regulat* or manage* or maintain $\left.\left.{ }^{\star}\right)\right)$

S14 hypo?therm* or normo?therm* or thermo?regulat* or shiver*

S13 (MM "Hypothermia") OR (MM “Body Temperature Regulation") OR (MM “Shivering")

\section{S12 S1 OR S2 OR S3 OR S4 OR S5 OR S6 OR S7 OR S8 OR S9 OR S10 OR S11}

S11 (MH "Quantitative Studies")

S10 (MH "Quantitative Studies")

S9 (MH "Placebos")

S8 TX placebo*

S7 TX random* allocat*

S6 (MH "Random Assignment")

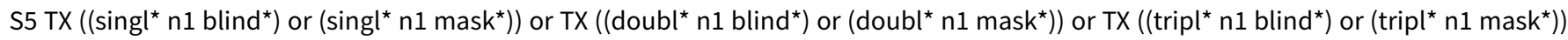
or TX ((trebl* $n 1$ blind $\left.{ }^{\star}\right)$ or $\left(\right.$ trebl $^{\star} n 1$ mask $\left.\left.^{\star}\right)\right)$

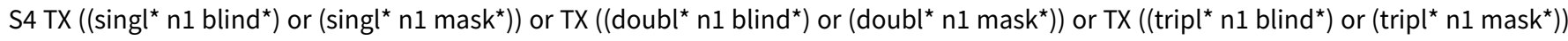
or TX ((trebl* $\mathrm{n} 1$ blind $\left.^{\star}\right)$ or (trebl* $\mathrm{n} 1$ mask $\left.\left.^{\star}\right)\right)$

S3 TX clinic ${ }^{*} 1$ trial ${ }^{*}$ 
S2 PT Clinical trial

S1 (MH "Clinical Trials+")

Appendix 6. Data extraction form

Cochrane Anaesthesia, Critical and Emergency Care Group

Study selection, quality assessment \& data extraction form

Pharmacological agents for preventing inadvertent perioperative hypother-

mia

\section{Code of paper:}

Reviewerinitials: Date:

First study author Journal/Conference proceedings, etc, $\quad$ Year

\title{
Study eligibility
}

\begin{tabular}{llll}
\hline RCT/Quasi/CCT (delete as appropriate) & Relevant participants & Relevant interventions & Relevant outcomes \\
\hline
\end{tabular}
Yes / No / Unclear
Yes / No / Unclear
Yes / No / Unclear
Yes / No* / Unclear

\begin{abstract}
* Issue related to selective reporting - when study authors may have taken measurements for particular outcomes but did not report these within the paper(s). Review authors should contact trialists for information on possible non-reported outcomes and reasons for exclusion from publication. Study should be listed in 'Studies awaiting assessment' until clarified. If no clarification is received after three attempts, study should then be excluded.
\end{abstract}

Do not proceed if any of the above answers is 'No'. If study is to be included in 'Excluded studies' section of the review, record below the information to be inserted into the 'Table of excluded studies'. 


\section{Methodological quality}

\section{Allocation of intervention}

State here the method used to generate allocation and reasons for grading. Grade (circle) (quote)

\section{Page no.}

Adequate (random)

Inadequate (e.g. alternate)

Unclear

\section{Concealment of allocation}

Process used to prevent foreknowledge of group assignment in an RCT, which should be seen as distinct from blinding

\begin{tabular}{lc}
\hline State here method used to conceal allocation and reasons for grading (quote) & Grade (circle) \\
\hline Page no. & Adequate \\
\cline { 2 - 2 } & Inadequate \\
& Unclear \\
\hline
\end{tabular}

\section{Blinding}

Page no.

\begin{tabular}{ll}
\hline Person responsible for participant care & Yes / No \\
\hline Participant & Yes / No \\
\hline Outcome assessor & Yes / No
\end{tabular}


(Continued)

Other (please specify)

Yes / No

\section{Intention-to-treat}

An intention-to-treat analysis is one in which all participants in a trial are analysed according to the intervention to which they were allocated, whether they received it or not.

Number of participants entering the trial

Number excluded

$\%$ excluded (greater than or less than $15 \%$ )

Not analysed as 'intention-to-treat'

\section{Unclear}

Were withdrawals described?

Yes / No / Not clear

Free text:

Participant and trial characteristics

Participant characteristics

Additional details

Page no.

Age (mean, median, range, etc.)

Sex of participants (numbers / \%, etc.)

\section{Trial characteristics}

Additional details

Page no.

Single centre / multi-centre

Country / Countries

How was participant eligibility defined?

How many people were randomized?

How many people were analysed?

Control group (size and details, e.g. 2 cotton blankets + fluid warmer + HME) 
(Continued)

Intervention group 1 (size and details)

Intervention group 2 (size and details)

Intervention group 3 (size and details)

Time treatment applied (e.g. 30 minutes preop)

Duration of treatment (mean + SD)

Total anaesthetic time

Duration of follow-up

Time points when measurements were taken during the study

Time points reported in the study

Time points you are using in RevMan

Trial design (e.g. parallel / cross-over ${ }^{\star}$ )

Other

* If cross-over design, please refer to the Cochrane Editorial Office for advice on how to analyse these data.

\section{Relevant outcomes}

\begin{tabular}{ll}
\hline & Reported in paper (circle) \\
\hline Infection and complications of surgical wound & Yes / No \\
\hline Major CVS complications (CVS death, MI, CVA) & Yes / No \\
\hline Risk of hypothermia (core temp) & Yes / No \\
\hline Pressure ulcers & Yes / No \\
\hline Bleeding complications & Yes / No \\
\hline Other CVS complications (arrhythmias, hypotension) & Yes / No \\
\hline Patient-reported outcomes (shivering, discomfort) & Yes / No \\
\hline All-cause mortality & Yes / No \\
\hline Adverse effects & Yes / No \\
\hline
\end{tabular}




\section{Relevant subgroups}

Page no.

\begin{tabular}{ll}
\hline Age $>80$ & Yes / No \\
\hline Pregnancy & Yes / No \\
\hline ASA scores & Yes / No \\
\hline Urgency & Yes / No \\
\hline
\end{tabular}

Subgroups

Number of participants

\begin{tabular}{llllll}
\hline & Age $>80$ & Pregnant & Elective & Urgent & ASA I or II ASA III or IV \\
\hline Control & & \\
\hline
\end{tabular}

\section{Intervention 1}

Intervention 2

\section{Intervention 3}

\section{Free text:}




\section{For continuous data}

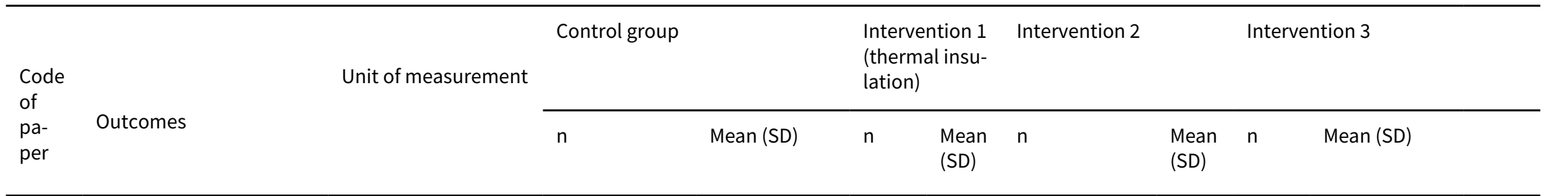

\section{Temperature at end of Degrees $C$}

surgery

Temperature at Degrees $C$

………........

Temperature

Degrees C

at ...................

Number of units red

cells transfused

\section{Units}

For dichotomous data ( $\mathrm{n}=$ no. of participants)

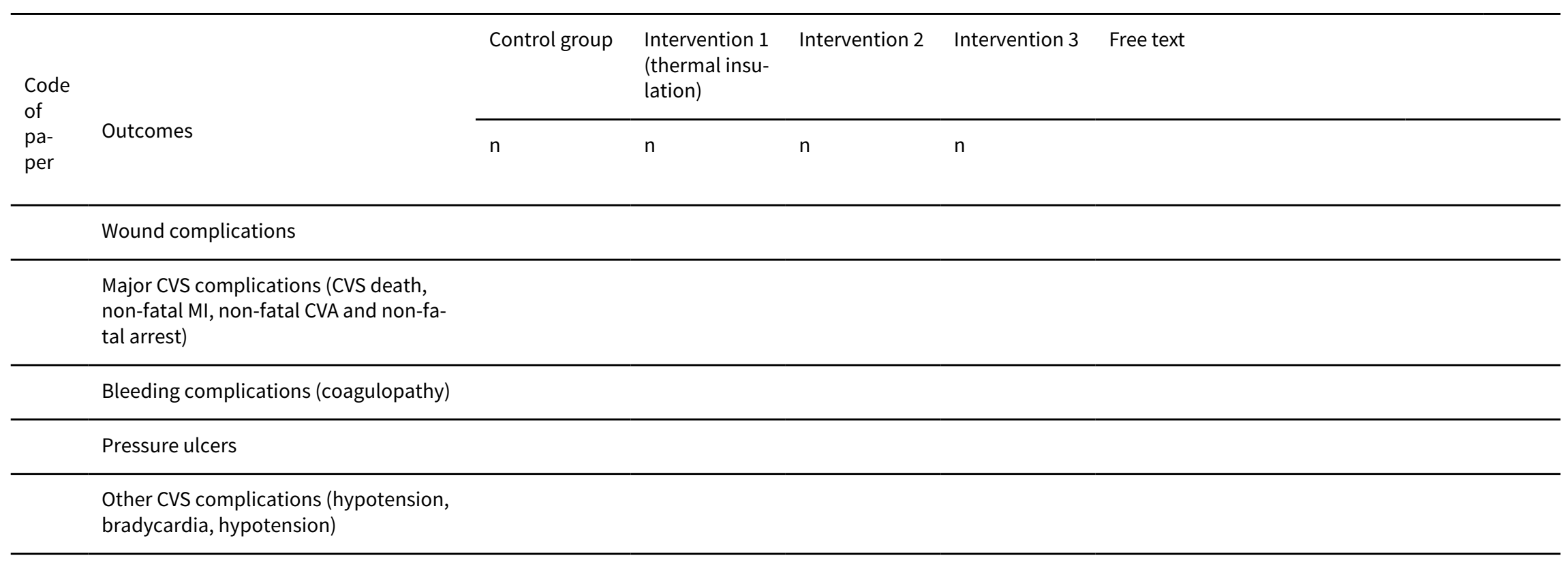

Other CVS complications (hypotension 


\section{Other information that you feel is relevant to the results}

Indicate if any data were obtained from the primary author; if results were estimated from graphs, etc. or were calculated by you via a formula (this should be stated and the formula given). In general, if results not reported in paper(s) are obtained, this should be made clear here to be cited in the review.

Free-hand space for writing actions such as contact with study authors and changes

References to trial

Check other references identified in searches. If you find additional references to this trial, link the papers now and list below. All references to a trial should be linked under one Study ID in RevMan.

\begin{tabular}{|c|c|c|c|}
\hline Code each paper & Study author(s) & Journal/Conference proceedings, etc. & Year \\
\hline
\end{tabular}

References to other trials

Did this report include any references to published reports of potentially eligible trials not already identified for this review?

\begin{tabular}{ll}
\hline First study author Journal / Conference $\quad$ Year of publication \\
\hline
\end{tabular}

Did this report include any references to unpublished data from potentially eligible trials not already identified for this review? If yes, list contact names and details. 


\section{CONTRIBUTIONS OF AUTHORS}

Sheryl Warttig (SW), Phil Alderson (PA), Sharon R Lewis (SL), Andrew F Smith (AS).

PA had the idea to update the NICE guideline (NICE 2008) review.

Conceiving of the review: PA.

Co-ordinating the review: SW.

Undertaking manual searches: PA.

Screening search results: SW, PA.

Organizing retrieval of papers: SL.

Screening retrieved papers against inclusion criteria: SW, PA.

Appraising the quality of papers: SW, PA.

Abstracting data from papers: SW, PA.

Writing to authors of papers for additional information: SW, PA.

Providing additional data about papers: not applicable.

Obtaining and screening data from unpublished studies: not applicable.

Managing data for the review: SW.

Entering data into Review Manager (RevMan 5.3): SW, PA.

Analysing RevMan statistical data: SW, PA.

Performing other statistical analysis not using RevMan: not applicable.

Interpreting data: SW, PA, SL, AS.

Making statistical inferences: SW, PA, SL, AS.

Writing the review: SW, PA.

Securing funding for the review: AS, PA.

Performing previous work that provided the foundation for the present study: not applicable.

Serving as guarantor for the review (one review author): PA.

Taking responsibility for reading and checking the review before submission: SW.

\section{DECLARATIONS OF INTEREST}

Sheryl Warttig: none known.

Phil Alderson: none known.

Sharon R Lewis: none known.

Andrew F Smith: none known.

See Sources of support.

\section{SOURCES OF SUPPORT}

\section{Internal sources}

- No sources of support supplied 


\section{External sources}

- National Institute for Health Research, UK.

NIHR has provided a grant for the preparation of Cochrane reviews relevant to perioperative care

\section{DIFFERENCES BETWEEN PROTOCOLANDREVIEW}

We have made the following changes to the original protocol (Alderson 2012).

1. Title: We have replaced 'pharmacological agents' with 'intravenous nutrients'. We did this to make the review more focused and specific; we replaced the word 'patients' with the word 'adults' to make the meaning more specific.

2. Authors: We changed the order of review authors and replaced one of the review authors (Gillian Campbell) with a new review author (Sharon Lewis). We also changed the contact author.

3. Background: We made minor amendments to the text to reflect the title change, and to make the meaning of sentences more clear.

4. Objectives: We made minor amendments to the text to reflect the title change from 'drug and intravenous nutrient use' to 'intravenous nutrient use' only.

5. Methods: We amended the types of interventions and comparisons to reflect changes made to the title of the review.

6. After publication of the protocol and gathering of results, we made post hoc decisions to use mean core temperature as our primary outcome, and to add observer-rated shivering as one of the secondary outcomes. We did this because none of the included trials reported any of the primary or patient-reported outcomes that were specified in the protocol.

7. We deleted previous text stating that a single search would be conducted for the suite of reviews on preventing perioperative hypothermia because we conducted a new search that was specific to this review.

8. Appendices: We replaced the previous search strategy with a new search strategy.

\section{INDEX TERMS}

\section{Medical Subject Headings (MeSH)}

*Body Temperature; Administration, Intravenous; Amino Acids [ ${ }^{*}$ administration \& dosage]; Fructose [ ${ }^{*}$ administration \& dosage]; Hypothermia [etiology] [*prevention \& control]; Isotonic Solutions [administration \& dosage]; Randomized Controlled Trials as Topic; Ringer's Lactate; Shivering; Sodium Chloride [administration \& dosage]; Time Factors

\section{MeSH check words}

Adult; Humans 